\title{
JURISPRUDENTIAL RULINGS RELATED TO WINDSIN PURITY BOOK A COMPARATIVE STUDY
}

Prof. Muhammad Najeeb Al-Jouani/ University of Fallujah / College of Islamic Sciences / dr.mohammed.najeeb@uofallujah.edu.iq/ 07829377679

Abstract: The research deals with the most important jurisprudential issues related to winds in the book of Purity. In introduction: I showed the reason for my choice of the topic and my methodology in it there are four sections: I showed in the first topic: Defining wind as a language and a term, and the difference between them and the wind... and that most of use the word "winds" (plural) in Qur'an is for mercy, and most of the word "wind" (singular) is for torture.

I showed in the second topic: that the pure water if some leaves, hay or weeds fall into it due to the wind, it remains pure as long as its delicacy has not disappeared.. and that if the water reaches two jars and is changed with impurity, then it is no longer pure if it is changed by the winds.... and that the wind has an effect on continuation in ablution. I showed in the third topic: it is disliked to urinate or defecate in the wind, and the validity of tayammum for whom his ablution is broken if he intended dirt when the wind blew, evoking the intention of tayammum before throwing it in his hands until the time of his throwing them and then wiping tayammum. And our last prayer is praise be to God, Lord of the Worlds.

Keywords: (jurisprudentialrulings, prayer, punity, tayammum, winds)

$r \cdot \tau$ 


\title{
الأحكام الفقهية المتعلقة بالرياح في الطهارة
}

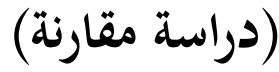

\author{
أ. م. د ميحّة نجيب الجوعاني / جامعة الفلوجة / كلية العلوم الإسلامية/
}

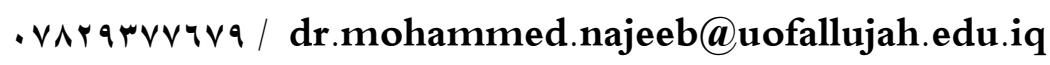

\section{الملنخص:}

الحمد لله والصلاة والسلام على سيدنا مُمَّمَ وعلى آله وصحبه ومن إهتدى بمداه... وبعد يتطرق البحث لأهم المسائل الفقهية المتعلقة بالرياح في كتاب الطهارة. وذلك من خلال تقسيمه الى: مقدمة: بينت فيها سبب إختياري للموضوع، ومنهجي فئل فئه ثم أربعة مباحث: مقدم: بينت فيها بينت في المبحث الأول: تعريف الرياح لغة وإصطلاحاً والفرق بينهما وبين الريح... وأن أغلب مافي القرآن الكريم من لفظ عيط (الرياح) عبارة عن الرحة وأغلب مافيه من لفظ (الريح) عبارة عن العذاب.

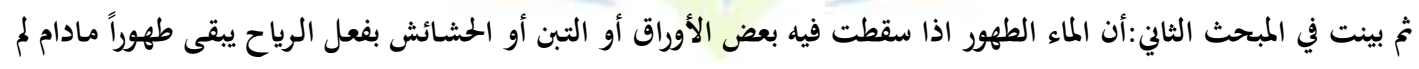

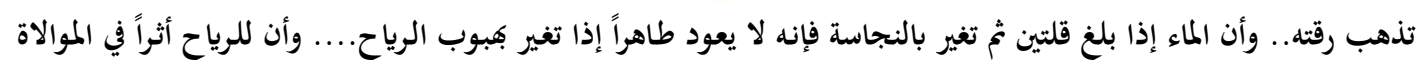
في الوضوء. ثم بينت في المبحث الثالث: كراهة التبول أو التغوط في مهب الريح، وصحة تيمم المحدث إذا قصد التراب حال هبوب الرياح

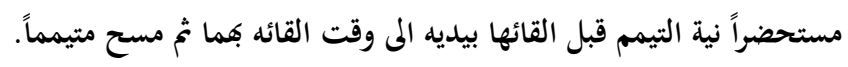

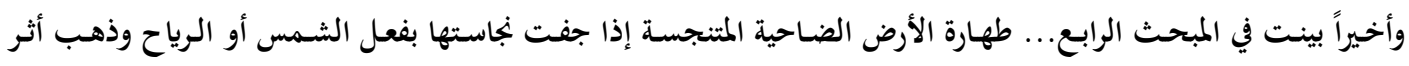

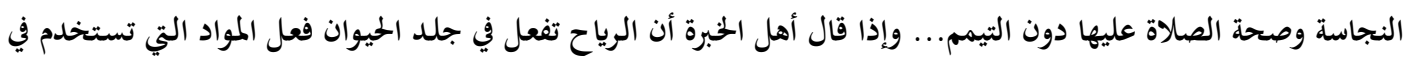

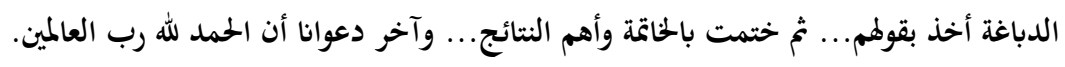
الكلمات المفتاحية: (الأحكام الفقهية، الصلاة، الظهارة، التيمم، الرياح).

$\Gamma \cdot V$ 


\title{
الأحكام الفقهية المتعلقة بالرياح في الطهارة
}

\section{(دراسة مقارنة)}

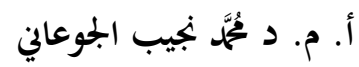 \\ جامعة الفلوجة / كلية العلوم الإسلامية الموانية
}

المقدمة

الحمد لله رب العالمين والصلاة والسلام على المبعوث رحمة للعالمين سيدنا مُمجمَّم وعلى آله الاشراف الطيبين وصحابته

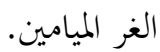

وبعد... فقد اطلعت في اثناء دراستي لبعض الكتب الفقهية على بعض المسائل المتعلقة بالرياح في كتاب الطهارة،

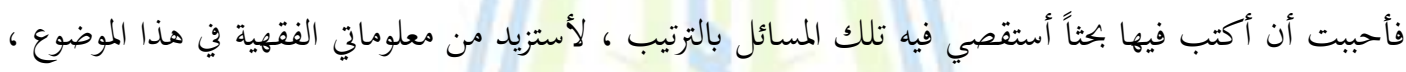

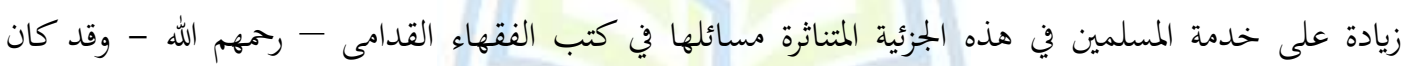

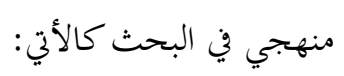
() التعريف بأهم المصطلحات التي أوردما في البحث من المعاجم اللغوية والاصطلاحية. r تخريج الأحاديث الشريفة من مصادرها مع بذل الجها في ذكر إسناد كل منها قدر المستطاع. r) عرض آراء الفتهاء واختلافاتم في كل مسألة مع ذكر أدلة كل فريق ومناقشتها ، ثم الترجيح بعد ذلك ذاكراً سبب الترجيح.

$$
\text { وقد قمت بتقسيم بكثي على أربعة مباحث هي: }
$$
المبحث الأول: مفهوم الرياح و الريح الفرق بينهما.

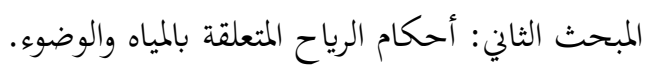

$r \cdot \Lambda$ 


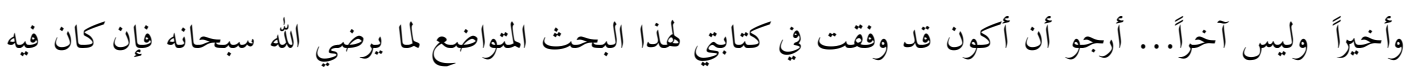

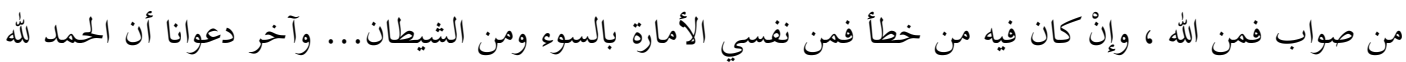

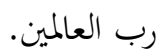

\section{الباحث}

r.q 


\section{المبحث الأول: مفهوم الرياح والريح الفرق بينهما

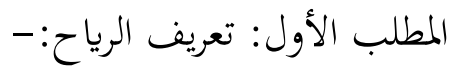

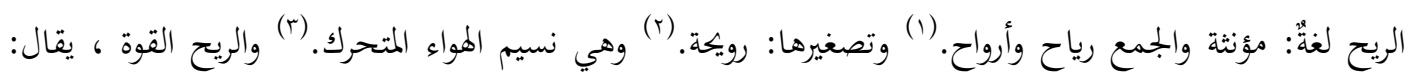

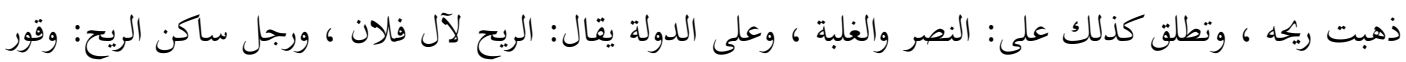

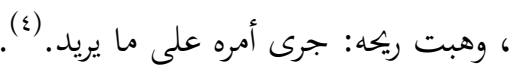
ولا يخرج المعنى اللغوي عن المعنى الاصطلاحي الشرعي ، باستناء أن الريح: تطلق أحياناً على الهواء الخارج من أحد

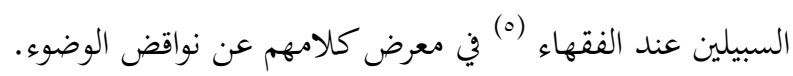

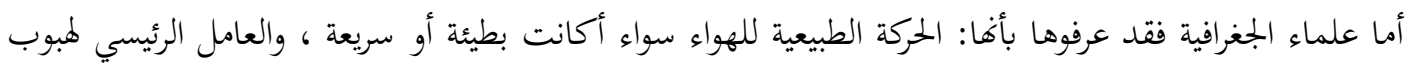

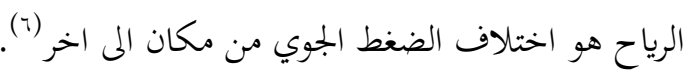

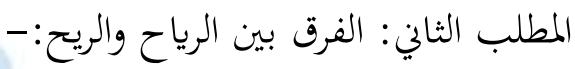
أغلب مافي القرآن من لفظ الجمع ، أي (الرياح) فعبارة عن الرمة ، وأغلب ما فيه من لفظ المفرد ، أي: (الريح)

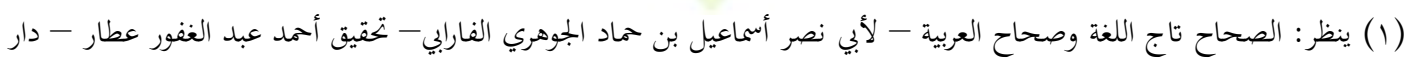

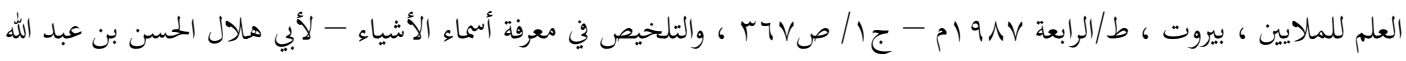

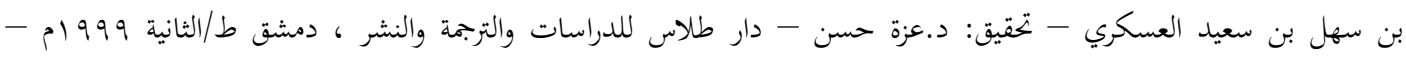

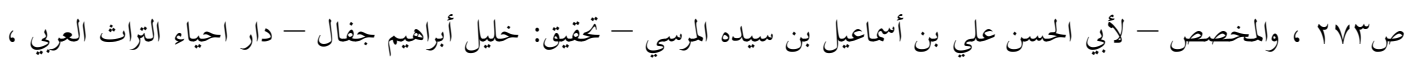

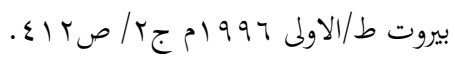

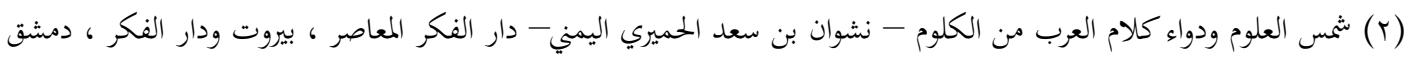

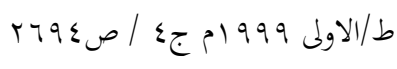

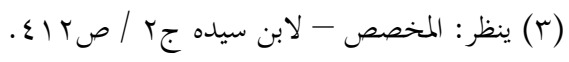

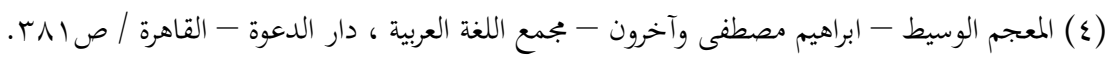

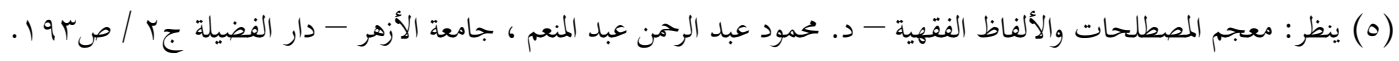

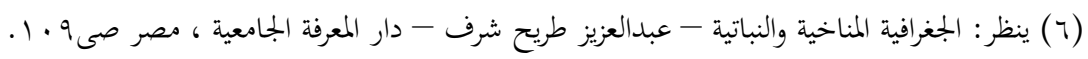
r). 


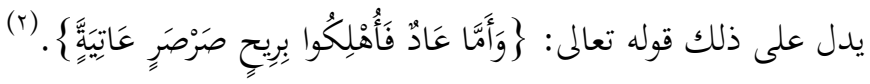

أي: بريح باردة شديدة البرد تحرق ببردها كإحراق النار مأخوذة من الصر وهو البرد (r).

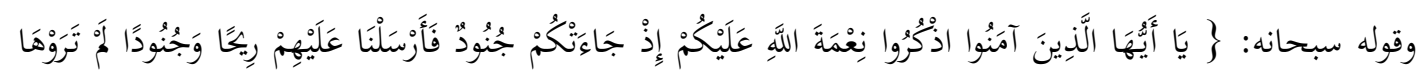

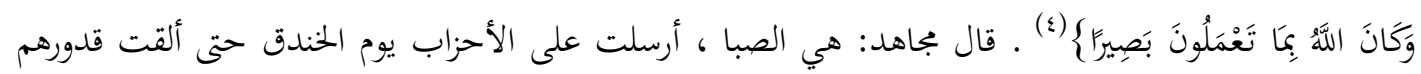

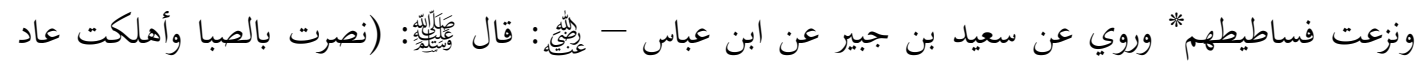

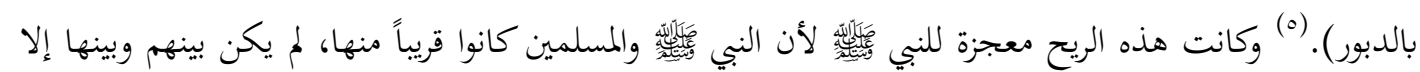
عرض الخندق ، وكانوا في عافية منها ، ولا خبر عندهم بها. (َ) وقال تعالى:

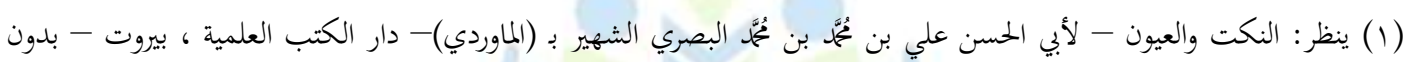

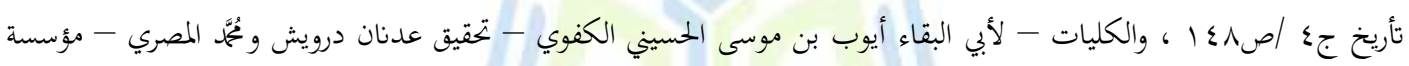

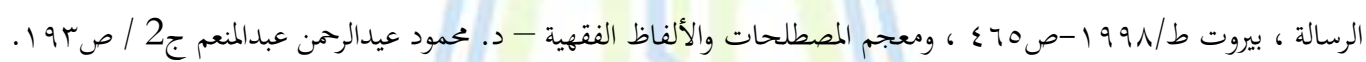

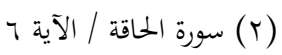
(r) ينظر: بحر العلوم - لابي الليث نصر بن مئمّ السمرقندي الحنفي - تحقيق: د. عممود مطرجي - دار الفكر ، بيروت - بدون

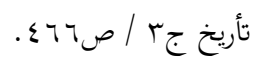
(ع) العورة الاحزاب / الاية 9.

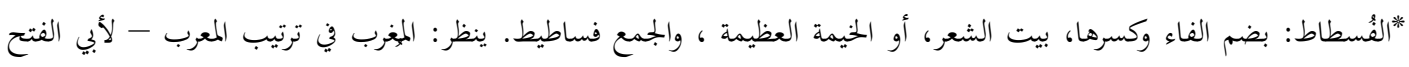

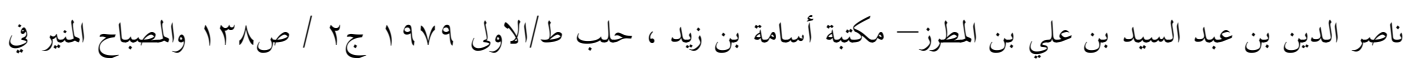

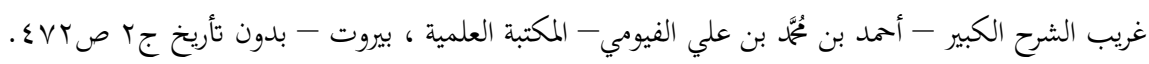

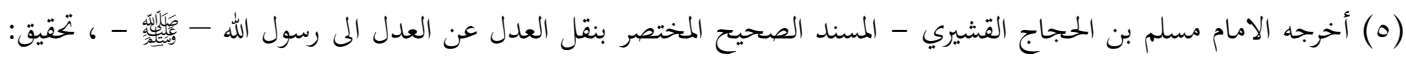

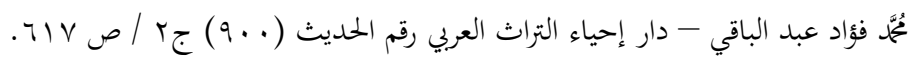

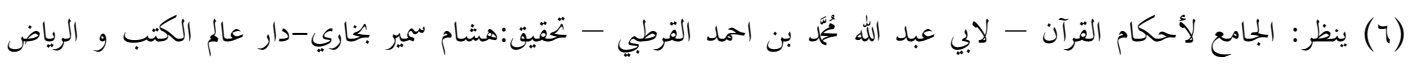

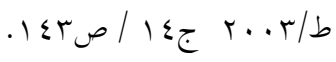

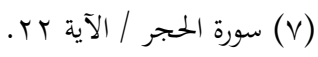

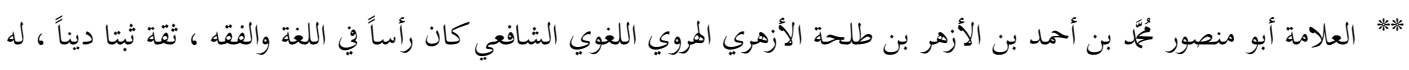

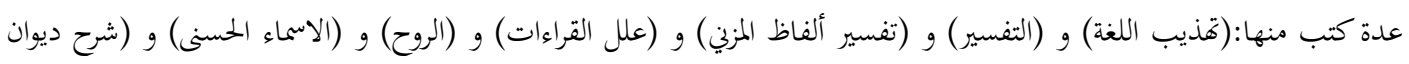
Ml 
ومعنى لواقح: حوامل، لأها تحمل الماء والتراب والسحاب والخير والنفع قال الأزهري**: وجعل الريح لاقحاً لأهما

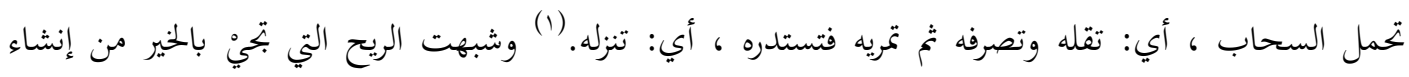

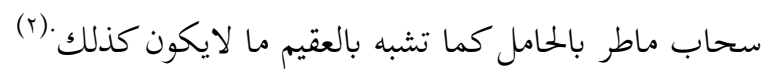

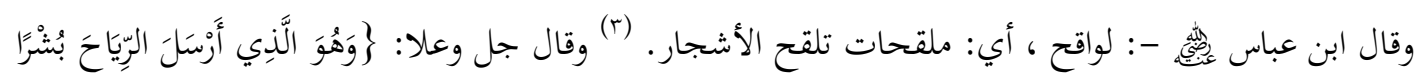

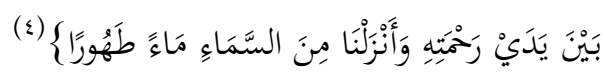

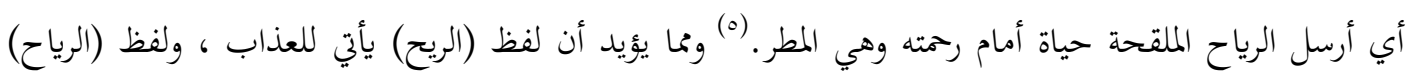

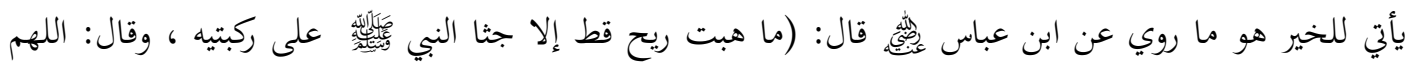

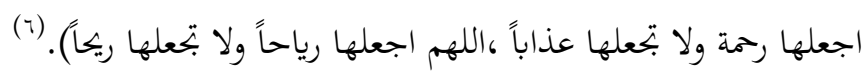

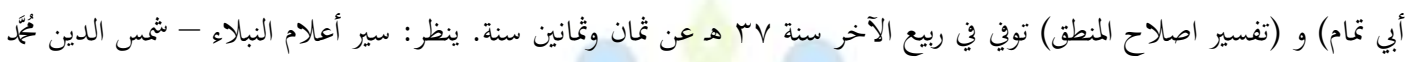

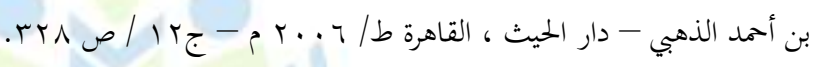

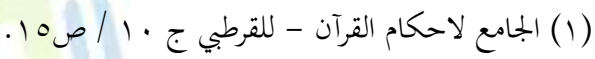

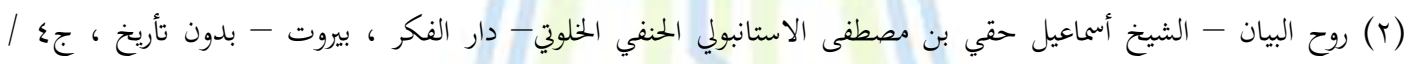
. sor

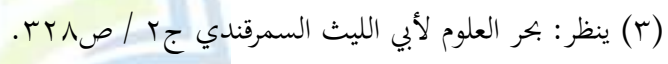

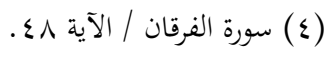

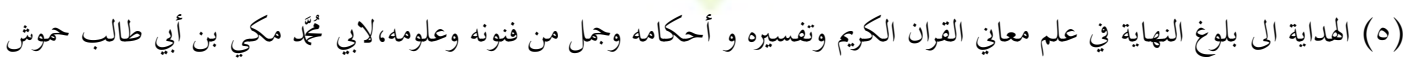

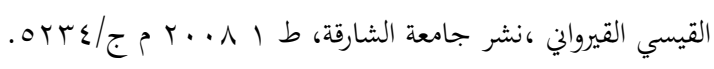

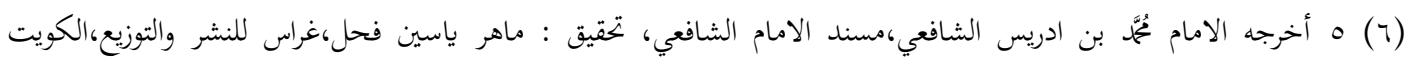

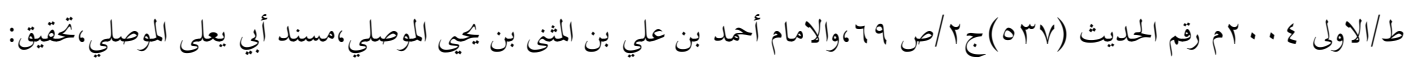

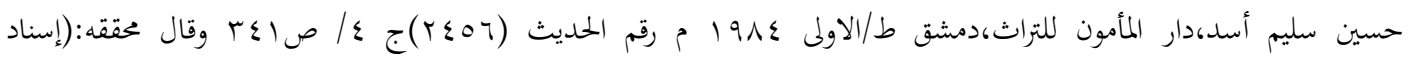

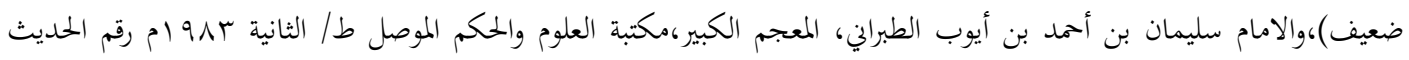

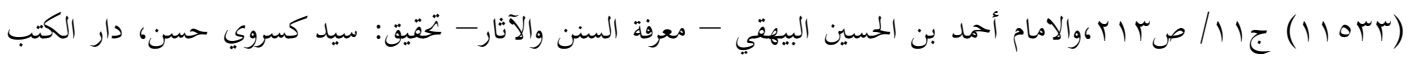

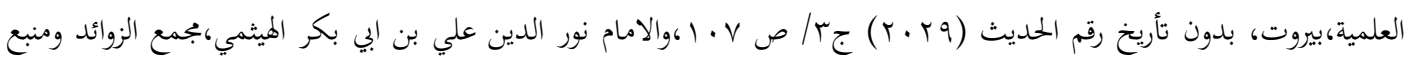

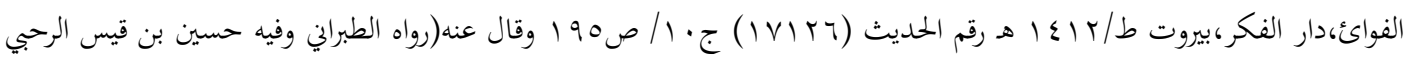

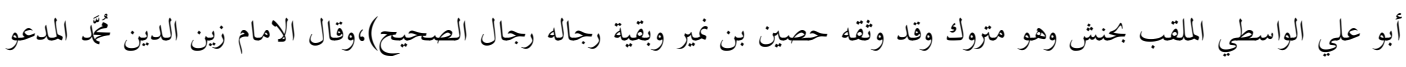

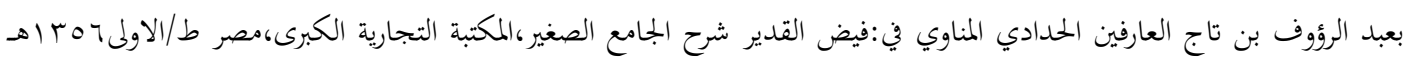
rit 


\section{Researcher Journal For Islamic Sciences}

\section{Published by the College of Islamic Sciences at the University of Fallujah}

ISSN p.p:2708-3993 / ISSN o.l: 2708-4000

Vol;1- Issue; 1/ (2020-2021)

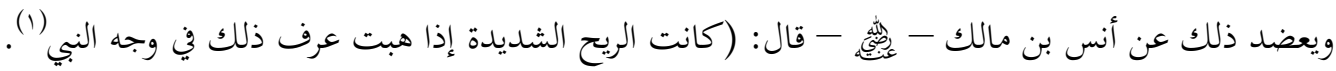
المبحث الثاني: أحكام الرياح المثعلقة بالمياه والوضوء

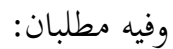

المطلب الأول: أحكام الرياح المتعلقة بالمياه: وفيه مسألتان: المسألة الأولى: حكم الماء المتغير بما تلقيه الرياح من طاهرات: اختلف الفقهاء في حكم الماء الطهور إذا سقطت فيه بعض الأوراق أو التبن أو الحشائش أو العيدان بفعل الرياح ،

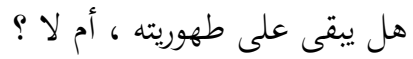

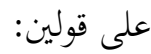
القول الاول: أذا تغير لون الماء بسبب كثرة الاوراق الساقطة فيه حتى ذهبت رقته وصار ثخيناً وزال عنه اسم الماء

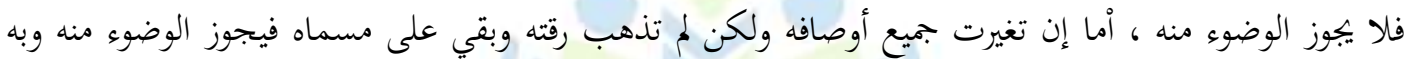

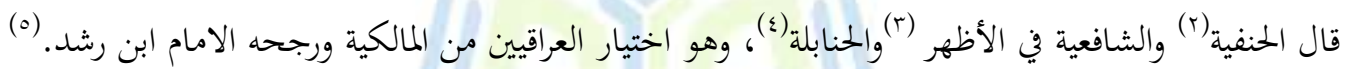

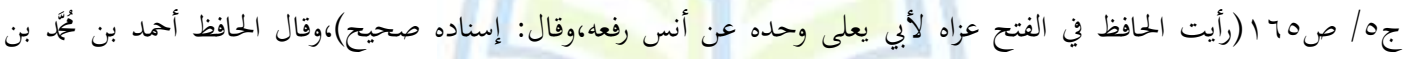

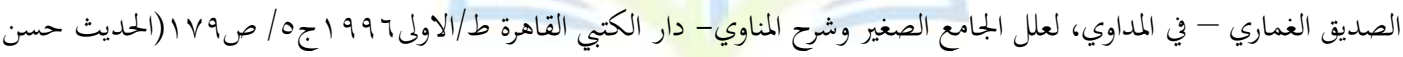

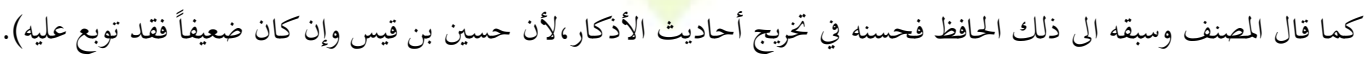

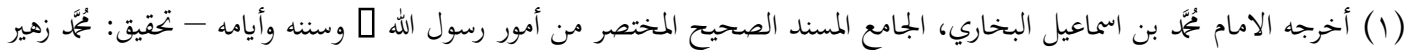

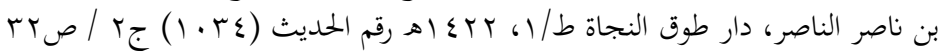

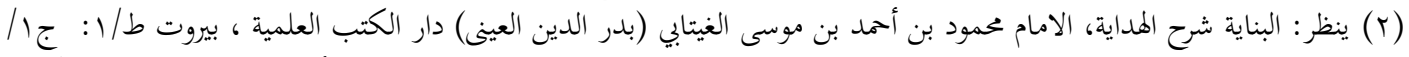

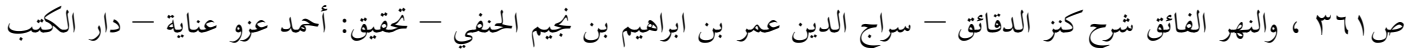

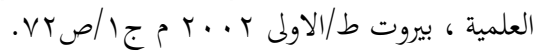

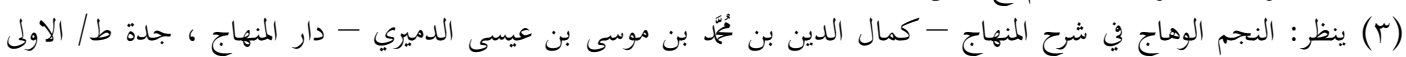

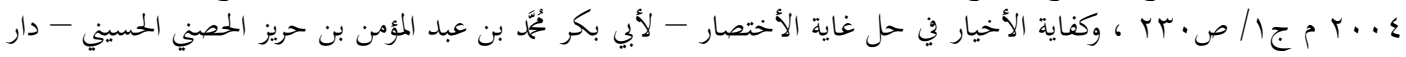

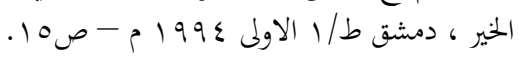

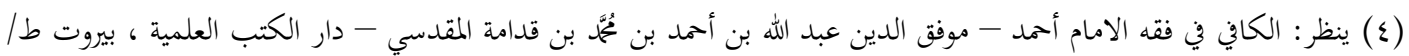

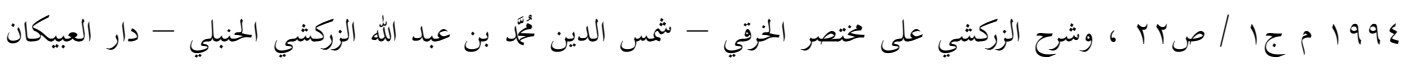

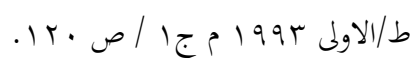

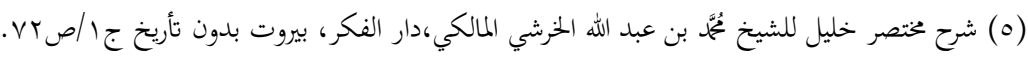

MT 


\section{Researcher Journal For Islamic Sciences}

Published by the College of Islamic Sciences at the University of Fallujah

ISSN p.p:2708-3993 / ISSN 0.l: 2708-4000

Vol;1- Issue;1/ (2020-2021)

وبإطلاق الماء الذي سقط فيه ورق الشجر قال فقهاء إلامامية وان تغير دون تفصيل(1)

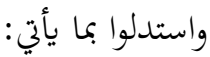

( ) لأن الماء تغير بكثرة الأوراق ، وكذلك لزوال اسم الماء عنه لثخنه. (r) r) لأنه لا يمكن الاحتراز عنه. (r) ولا يمكن صون الماء منه. (؛) فأصبح الأمر كأنه ضرورة. القول الثاني: إن ما تلقيه الرياح من ورق الاشجار أو الحشيش أو التبن في الماء يسلبه الطهورية ويجعله طاهراً غير

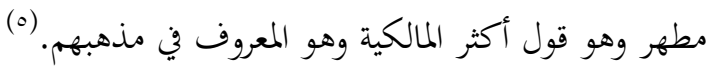

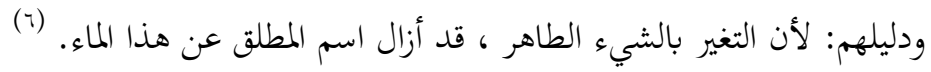
الترجيح: - (lin

والذي أميل اليه مما تقدم هو رأي جمهور الفقهاء وهو ان الماء طهور ولو تغير بشيْ مالم يخجر عن مسمى الماء ، وذلك لما إستدلوا به من أدلة أراها وجيهة ، يعضد ذلك بعض الأحاديث التي تدل على جواز التطهر بالماء الذي تغير بشيء طاهر مثل:

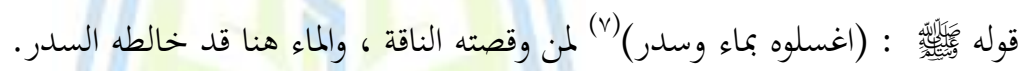

(1) ينظر: الفقه على المذاهب الخمسة - مُحَّمّ جواد مغنية - مؤسسة الصادق للطباعة والنشر - طهران ط/الخامسة - بدون تأريخ

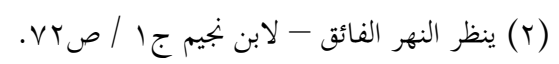

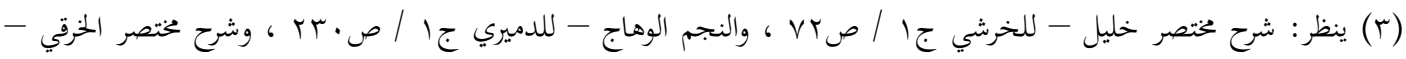

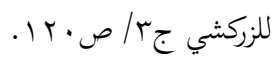

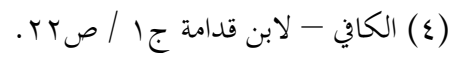

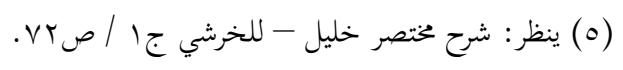

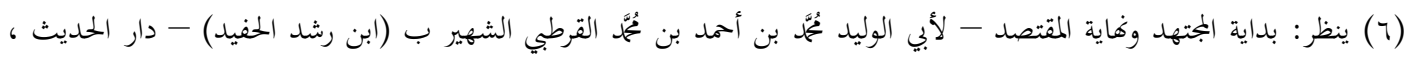

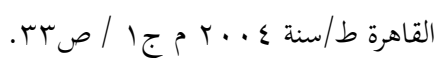

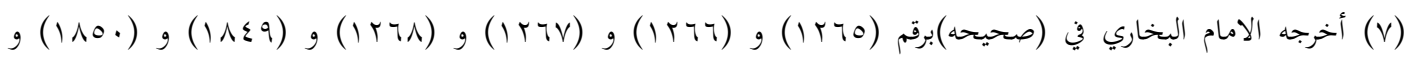




\section{Researcher Journal For Islamic Sciences}

\section{Published by the College of Islamic Sciences at the University of Fallujah \\ ISSN p.p:2708-3993 / ISSN o.l: 2708-4000}

Vol;1- Issue; 1/ (2020-2021)

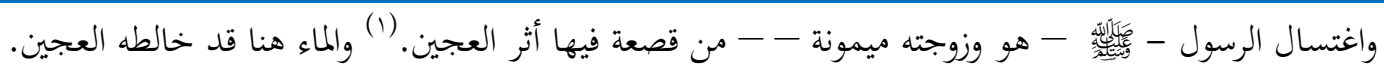

المسألة الثانية: تغير الماء النجس بفعل الرياح:-

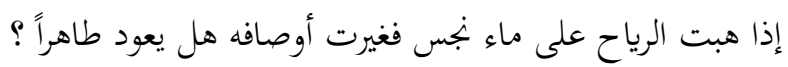
اختلف الفقهاء في ذلك على قولين:

ذهب جمهور الفقهاء من الحنفية والمالكية والحنابلة: المى أن الريح لا تعد وسيلة من وسائل تطهير الماء النجس

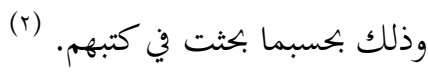

ووافقهم في ذلك الامامية فقالوا: (.. لا يطهر بزوال التغير من نفسه، ولا بتصفيق* الرياح) (r) ولم يذكروا دليلاً لقوهم.

وذهب الشافعية: الم أن الماء إذا بلغ قلتين *** ينجس إذا تغير بالنجاسة وإن كان التغير يسيراً ، ولكنه يعود طاهراً

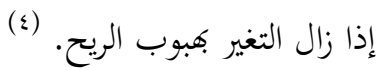

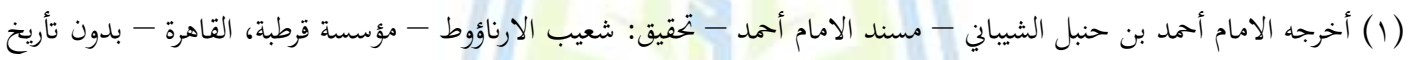

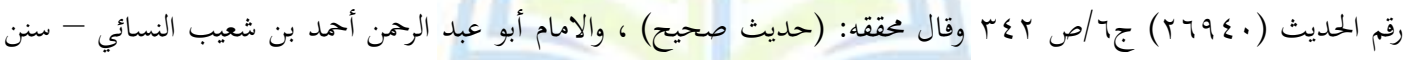

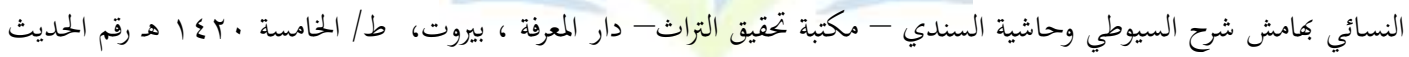

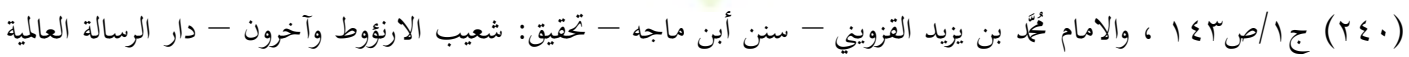

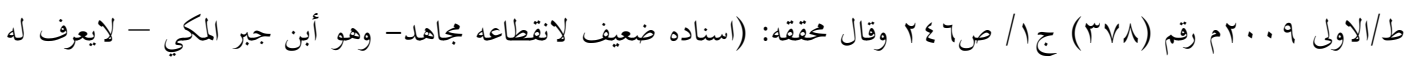

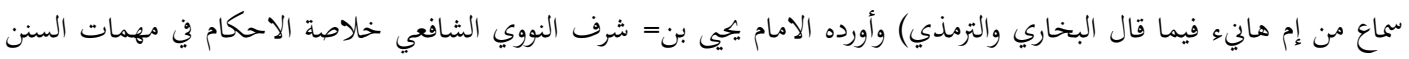

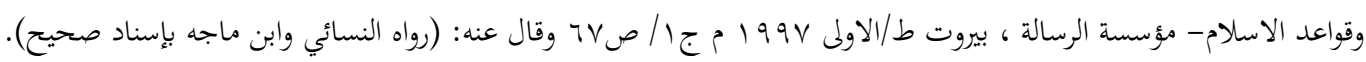

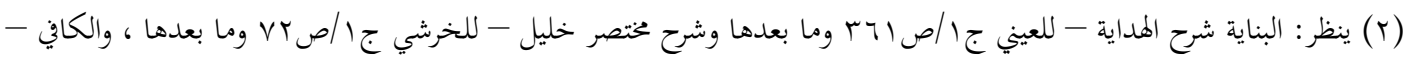

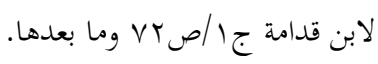

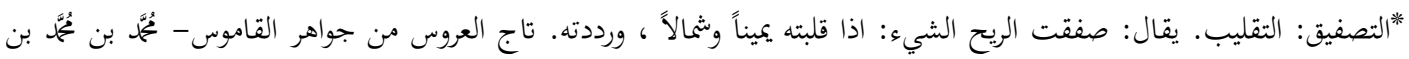

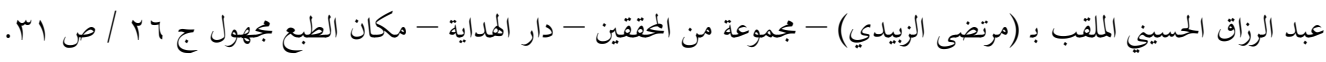

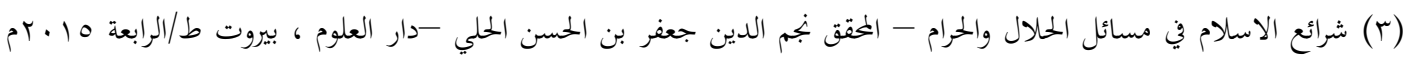

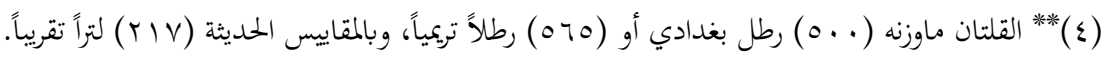

Mo 
والحجة عند الشافعية: هو أفم حكموا بنجاسة الماء الكثير لتغيره ، فإذا زال سبب النجاسة عمل المقتضى للطهارة

عمله. (1)

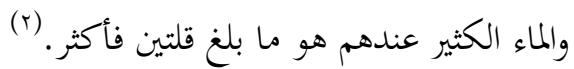

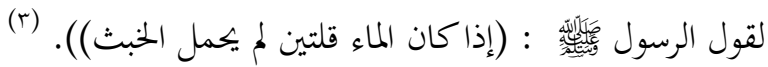

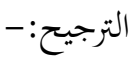

والذي أميل اليه أن تغير الماء النجس بواسطة الرياح لا يؤدي الى طهارته لان الرياح غالباً لا تغير الا رائحته النتنة

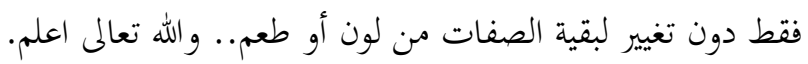

التقريرات السديدة في المسائل المفيدة -الشيخ حسن بن أحمد بن مُمَّم الكاف - دار العلم والدعوة ، اليمن ط/ الاول r . ب م ص

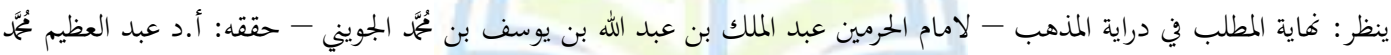

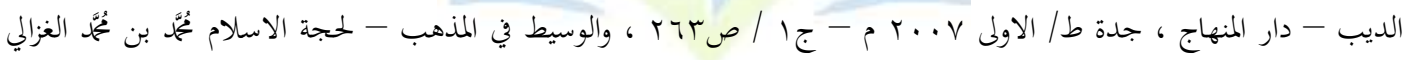

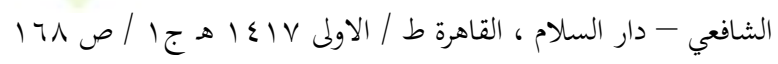

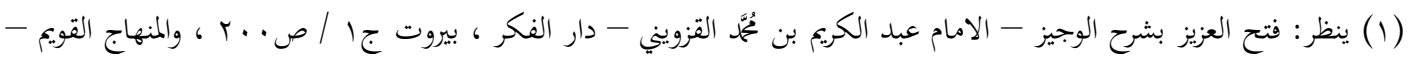

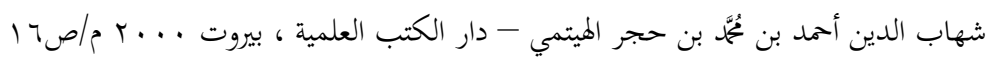

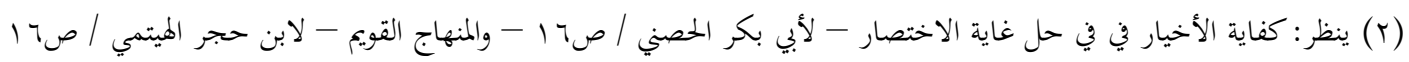

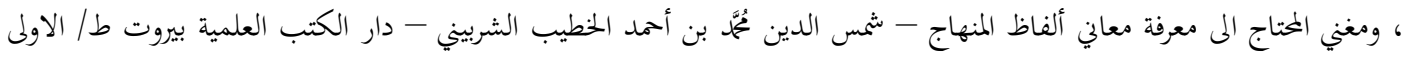

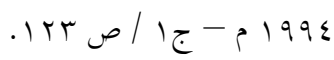

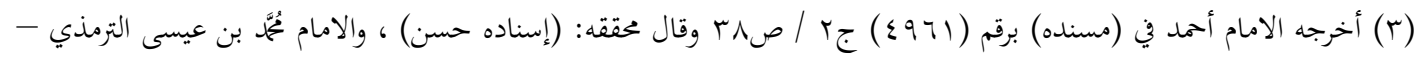

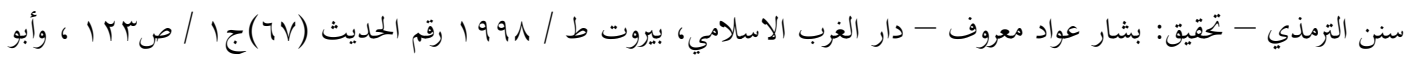

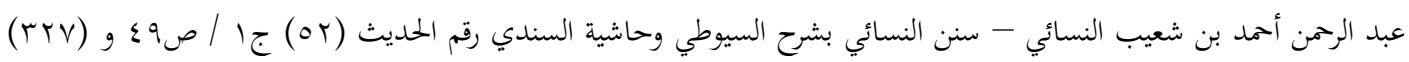

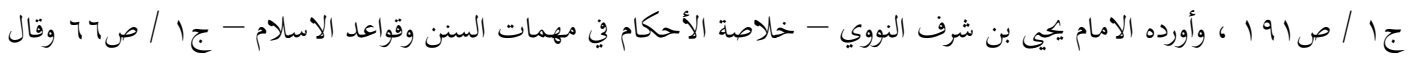
MIT عنه: (رواه الثلاثة وهو صحيح صححه الحفاظ). 


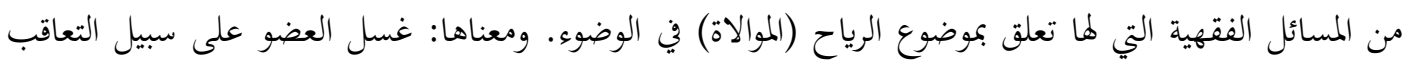

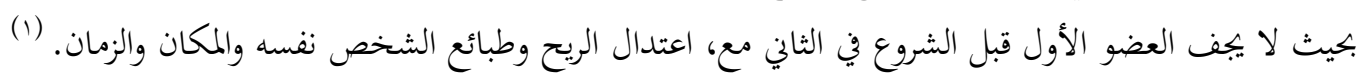

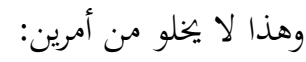

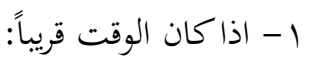
فالقريب: معفو عنه لا تأثير له في الوضوء ، وحده ما لم بتجف الأعضاء مع اعتدال المواء في غير برد ولا حر مشتد ،

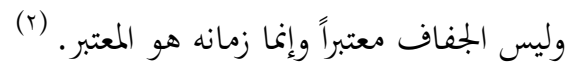

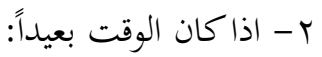

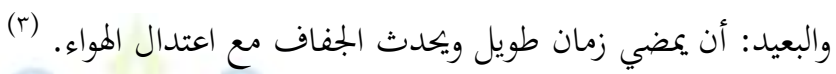
وقد اختلف الفقهاء فيه على ثلاثة أقوال: القول الأول: بأنه غير جائز والوضوء معل غير صحيح، لأن الموالاة واجبة وبه قال من الصحابة عمر ابن الخطاب

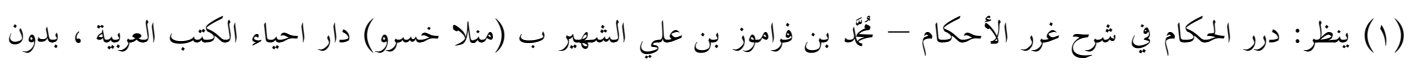

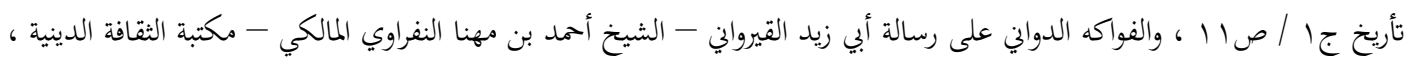

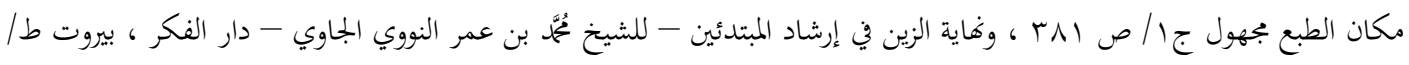

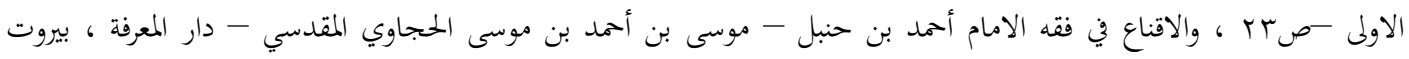

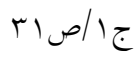

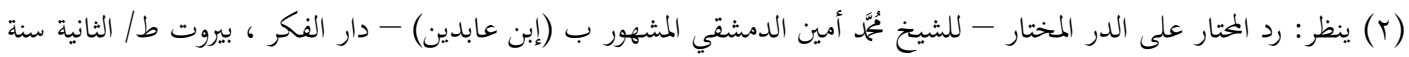

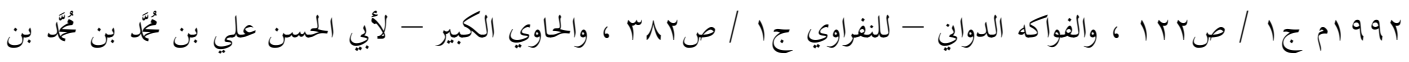

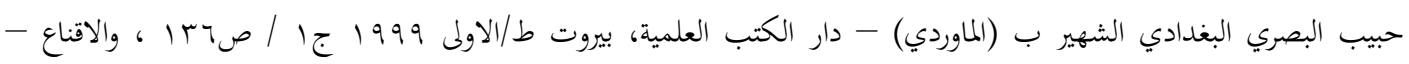

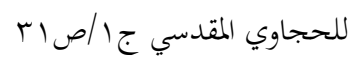

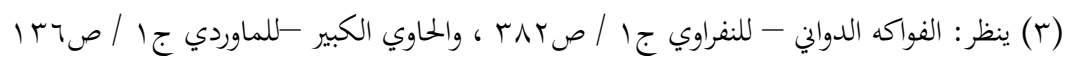


واستدلوا بما يأتي:

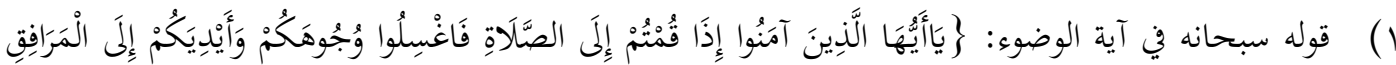

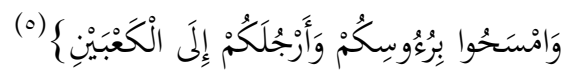

ومطلق أمر الله تعالى يقتضي الفور والتعجيل وذلك يمنع من التأجيل. (؟)

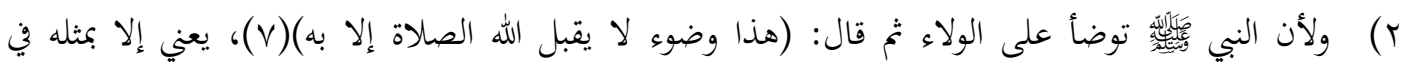
(الموالاة)

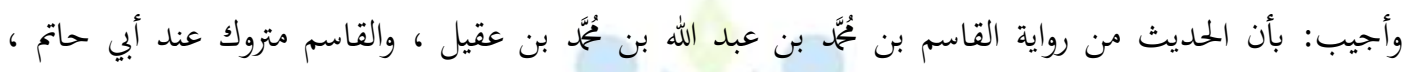

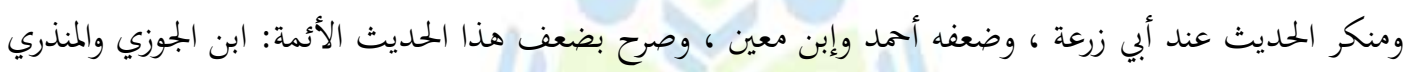
وابن الصلاح والنووي وغيرهم (1) فلا يصلح للاستدلال.

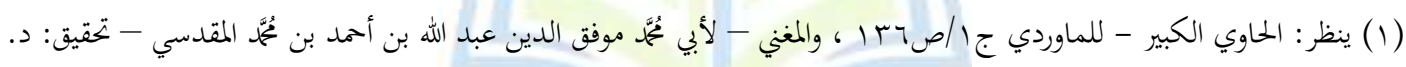

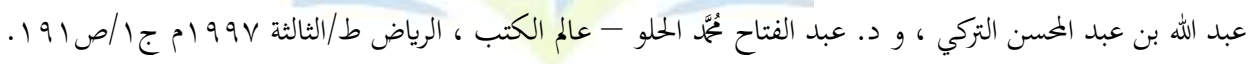

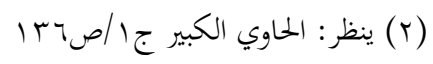

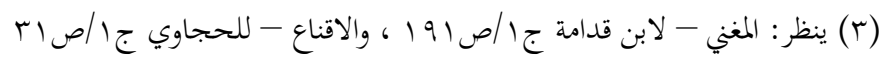

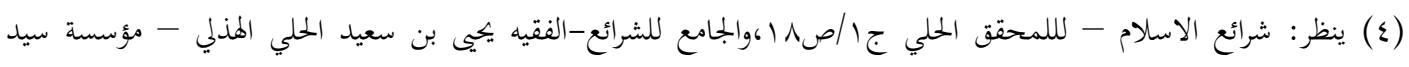

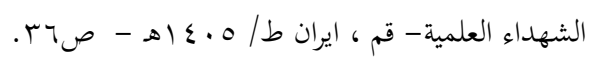

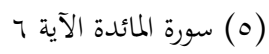

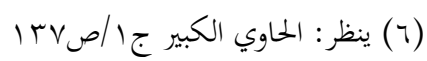

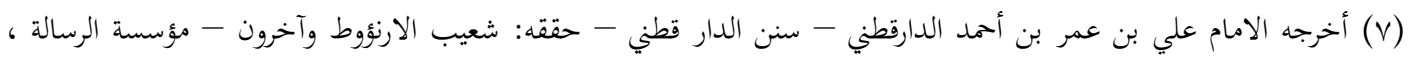

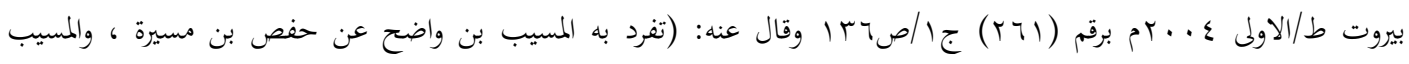

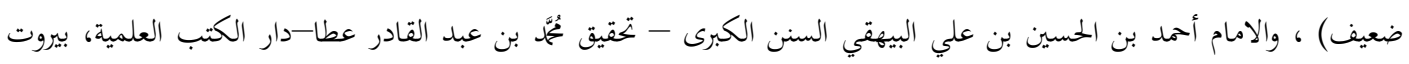

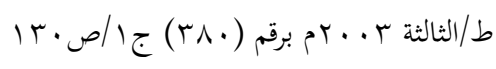

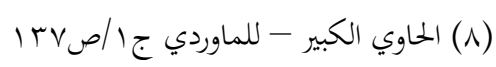

TIN 


\section{Researcher Journal For Islamic Sciences}

Published by the College of Islamic Sciences at the University of Fallujah

ISSN p.p:2708-3993 / ISSN o.I: 2708-4000

Vol;1- Issue;1/ (2020-2021)

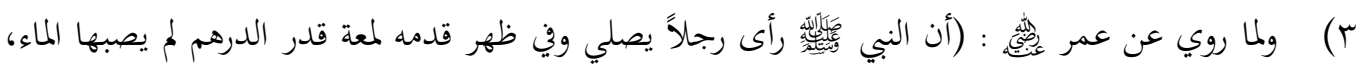

$$
\text { فأمره النبي (r) }
$$

$$
\text { ع) ولو لم بحب الموالاة لأجزأه غسل اللمعة.(r) }
$$

§) ولأها عبادة يفسدها الحديث ، فاشترطت لها الموالاة كالصلاة.(§)

القول الثاني: انه جائز والوضوء معه صحيح ، لأن الموالاة في الوضوء سنة ، وبه قال من الصحابة عبد الله بن عمر،

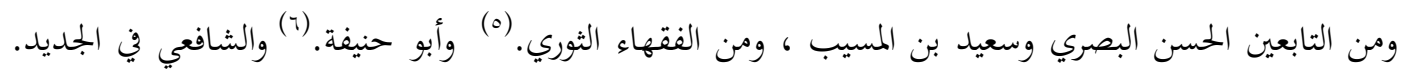

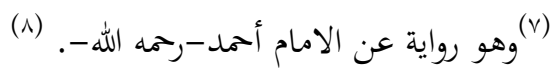

واستدلوا بما يأتي:

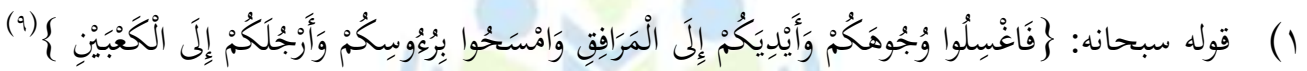

(1) ينظر: التلخيص الحبير في تخريج احاديث الرافعي الكبير - لأبي الفضل أممد بن علي بن مُحمّم بن حجر العسقلاني - دار الكتب

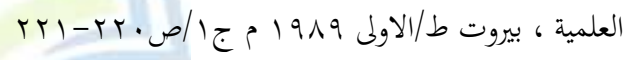

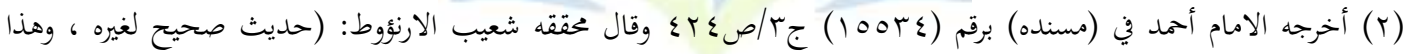

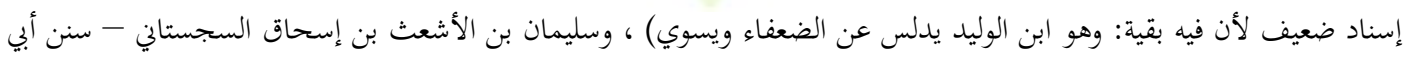

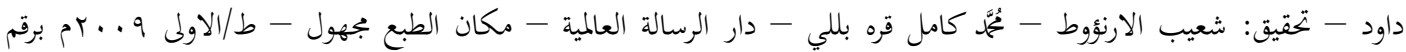

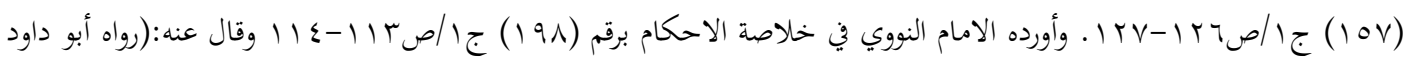

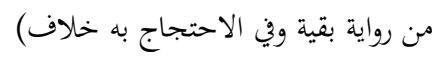

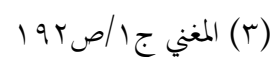

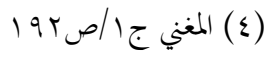

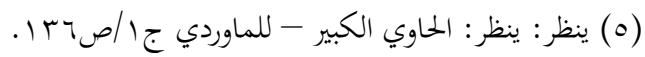

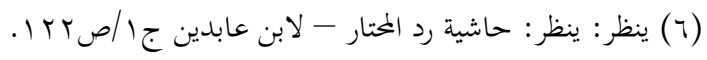

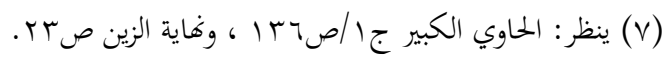

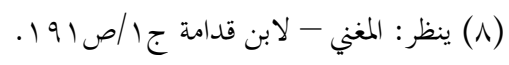


فظاهر الآية يدل على أن المأمور به غسل الأعضاء فكيفما غسل جاز.(1)

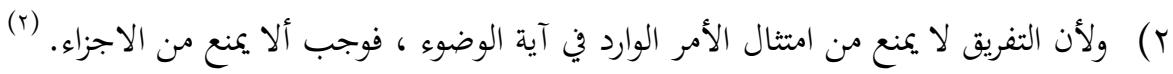

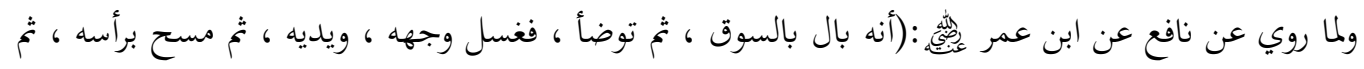

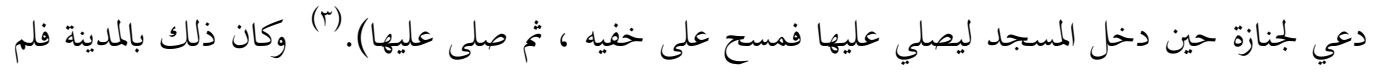
ينكر ذلك عليه أحد. (๕)

وأجيب: لأنه كان برجليه علة فلم يمكنه الجلوس في السوق حتى أتى المسجد فجلس ومسح والمسجد قريب من

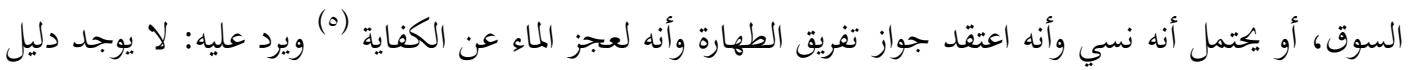
دليل صريح على هذه التأويلات والاحتمالات المختلفة.

r) ولأها إحدى الطهارتين فلم تجب الموالاة فيها كالغسل. (?) ع) ولأن كل عبادة جاز تفريق النية على أبعاضها ، جاز تفريق أبعاضها كالزكاة ، وبيان ذلك: أنه لما جاز

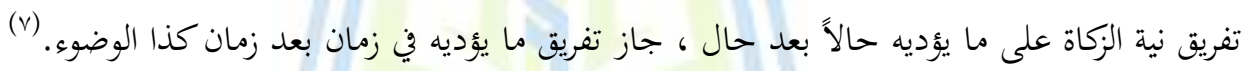

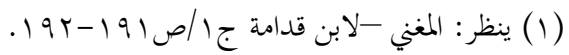

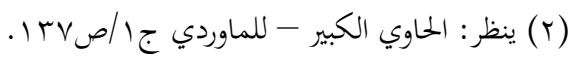

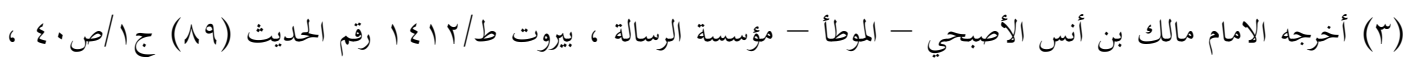

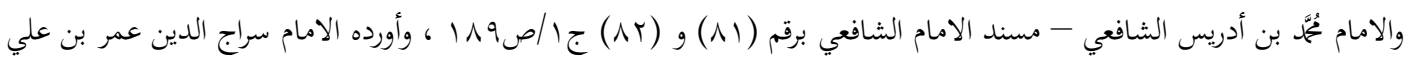

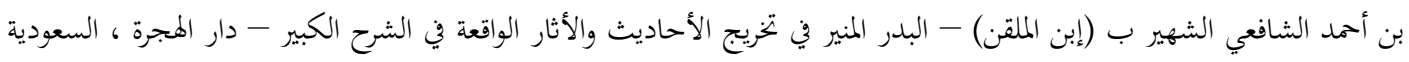

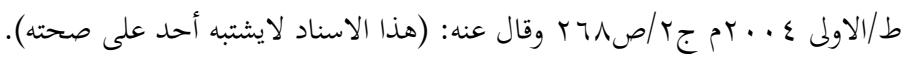

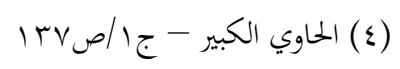

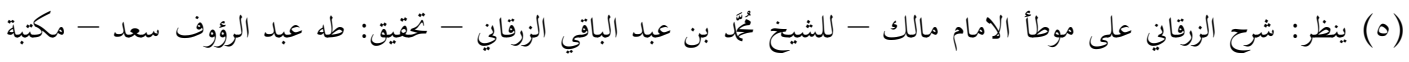

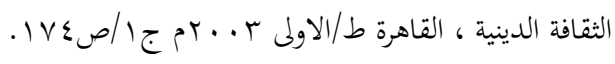

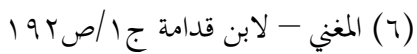

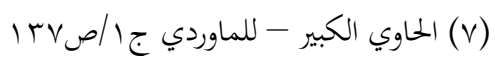

r. 
7) ولأن كل عبادة جاز فيها التفريق اليسير جاز فيها التفريق الكثير كالحج طرداً، والصلاة عكساً.(r) القول الثالث: إن الموالاة مع التذكر واجبة ، فإن فرق وضوءه ناسياً فلا شيء عليه، أو عامداً أعاد الوضوء لتهاونه ،

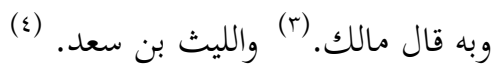
واستدلوا بما يأتي:

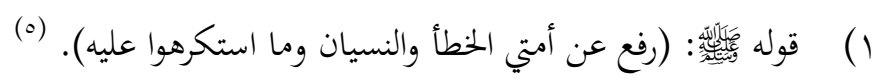

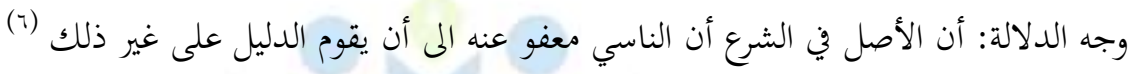

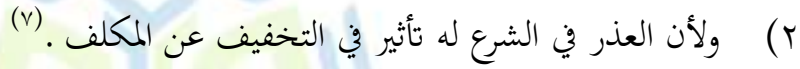

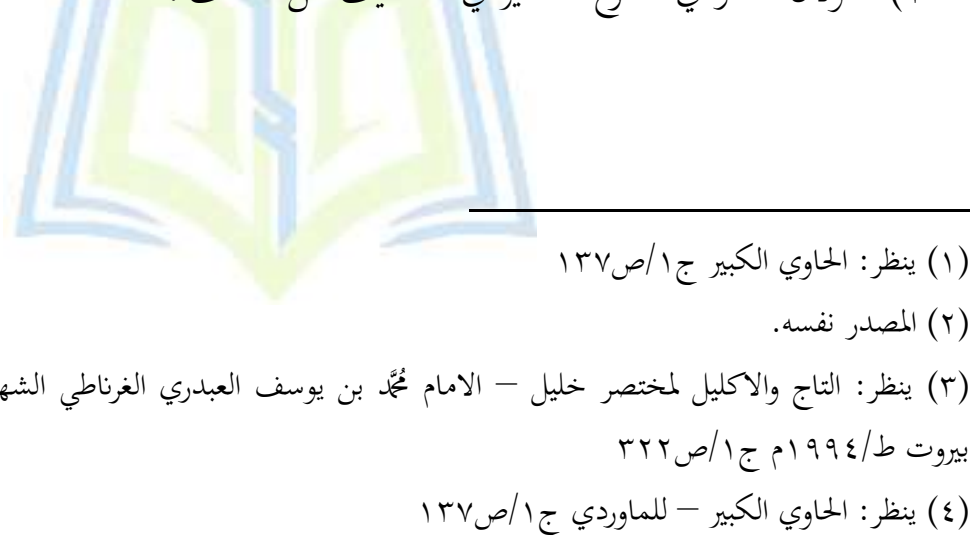

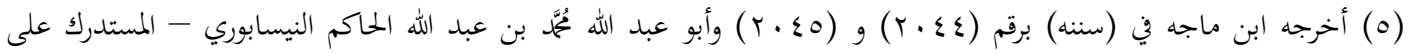

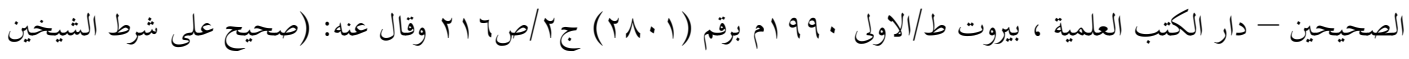

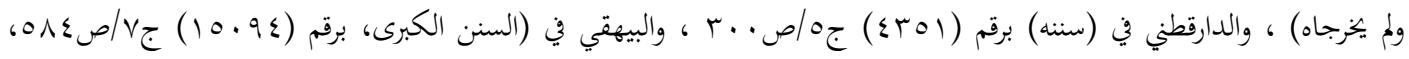

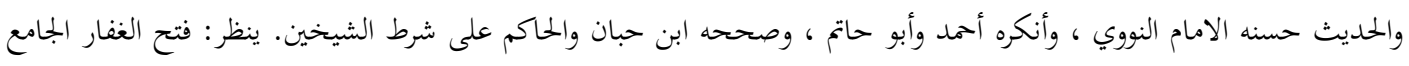

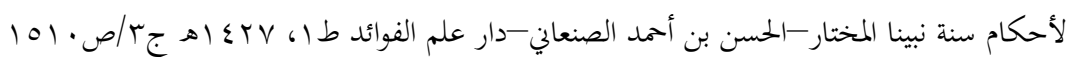

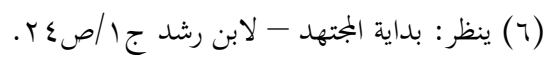

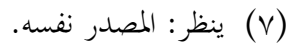


والذي أميل اليه مما تقدم من أقوال فقهية هو القول الثاني والذي يرى أصحابه أن الموالاة في الوضوء سنة وبتالي لا

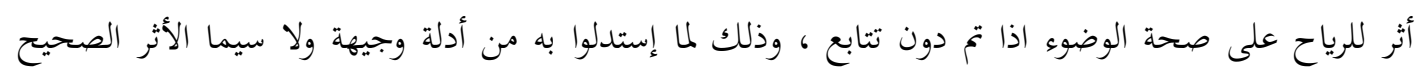

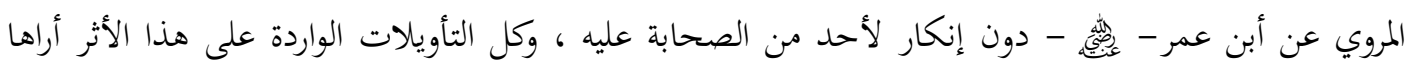

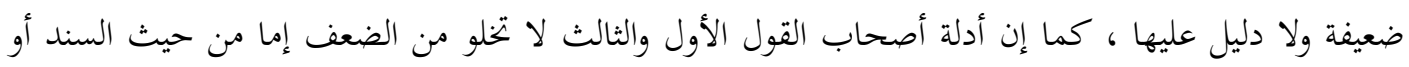
من حيث الاستدلال كما مر معنا.... والله تعالى أعلم.

\section{المبحث الثالث: أحكام الرياح المتعلقة بقضاء الحاجة والتيمم} ويمتوي على مطلبين: المطلب الأول: أحكام الرياح المتعلقة بقضاء الحاجة: وفلئ: وفيه مسألة واحدة:

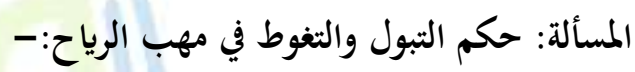
يكره التبول والتغوط في مهب الريح باتفاق الفتهاء. (1)

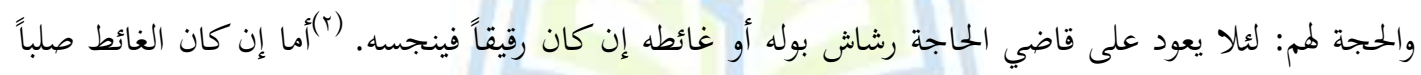

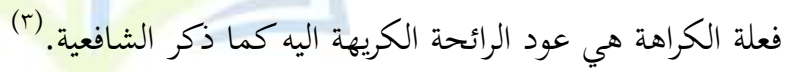

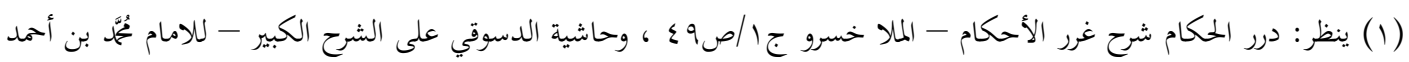

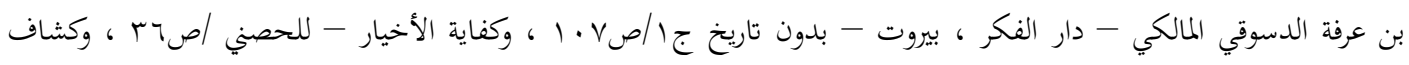

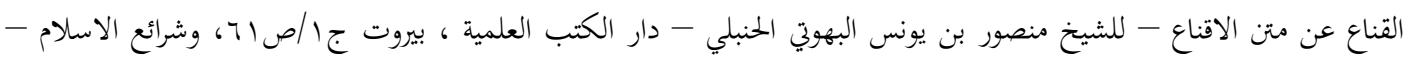

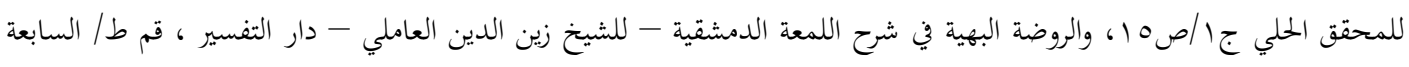

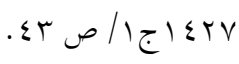

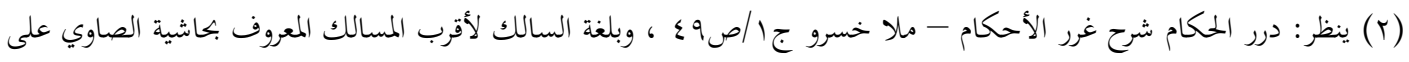

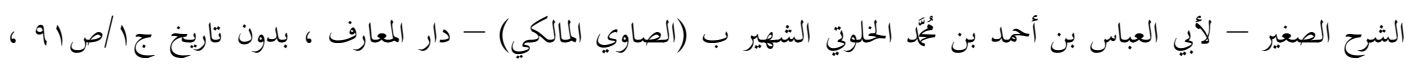

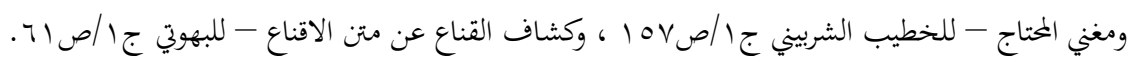
TYY

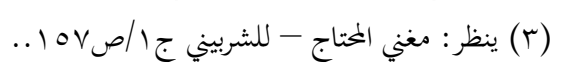




$$
\begin{aligned}
& \text { المطلب الثاني: أحكام الرياح المتعلقة بالتيمم: } \\
& \text { وفيه مسألة واحدة: } \\
& \text { المسألة: حكم التيمم بالتراب الذي نسفته الريح على الخحدث:- } \\
& \text { إختلف الفقهاء في هذه المسألة على ثلاثة أقوال: }
\end{aligned}
$$

القول الاول: لو ألقت الريح الغبار على وجهه ويديه فمسح بنية التيمم أجزأه ، وإن لم يمسح لم ميجزهاه وهو مذهب (1) الحنفية. (لاول:

واستدلوا بما يأتي:

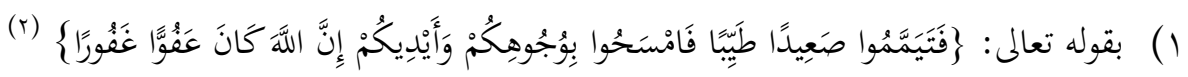

وجه الدلالة: أن الذي يقتضيه النظر عدم جعل ضربة الأرض من مسمى التيمم شرعاً فإن المأمور به في الآية المسح (r) (r) وجه الا

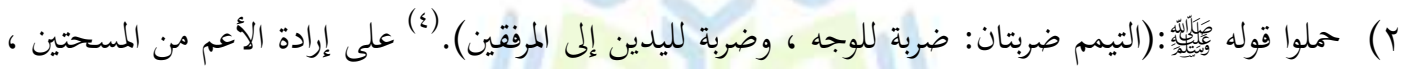

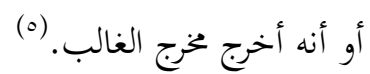

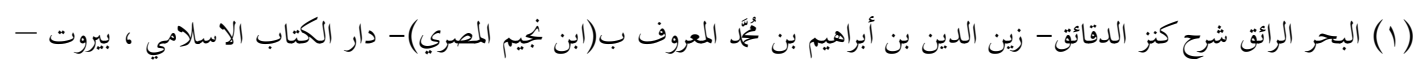

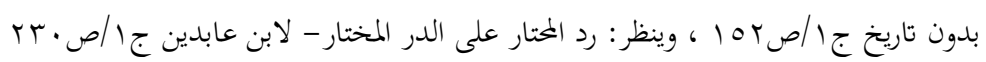

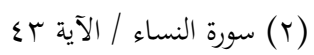

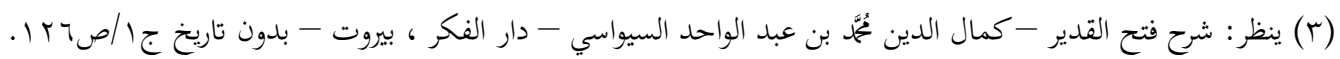

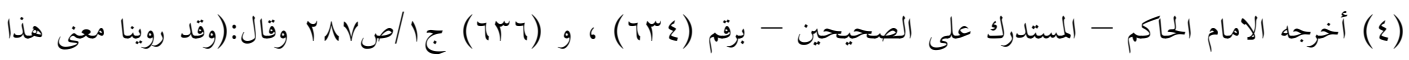

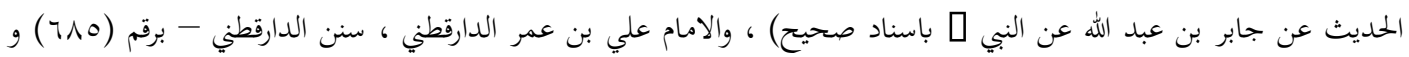

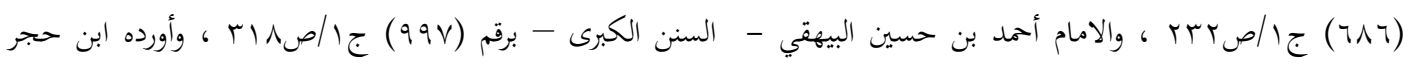

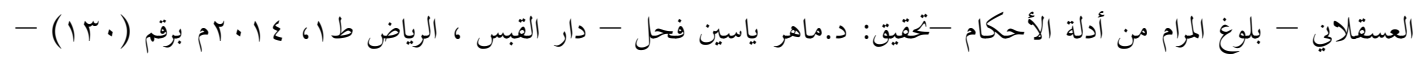

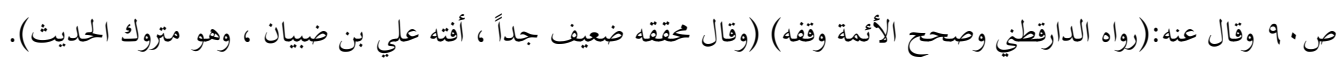
TrT

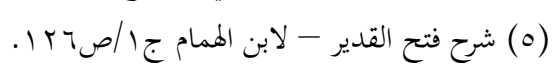




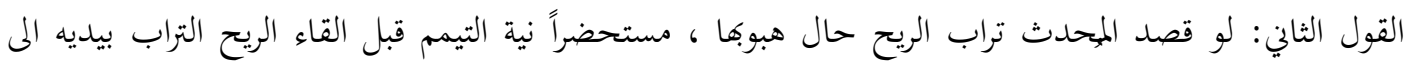

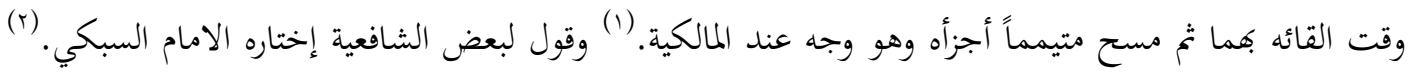
ووجه قوي عند الحنابلة. (r) واستدلوا بما يأتي:

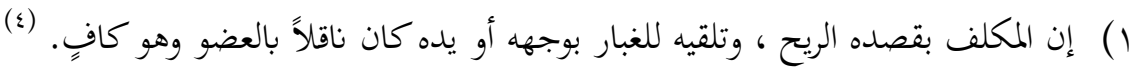
ولأنه قصد إيصال التراب إلى العضو بقصده ، فصار كما لو جلس تحت ميزاب ونوى الوضوء. (0) ويرد عليه: بأن الطهارة بالماء قوية ، بخلاف الطهارة بالتراب. (ج)

القول الثالث: لا يجزئ المحدث ذلك حتى لو قصد الريح ، وهو الأصح عند الشافعية. (v) ووجه عند المالكية. (^)

(1) ينظر: شرح الزرقاني على ختصر خليل - الامام عبد الباقي بن يوسف بن أممد الزرقاني - دار الكتب العلمية ، بيروت ط/الأولى

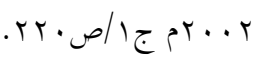

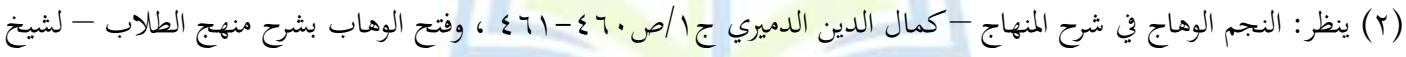

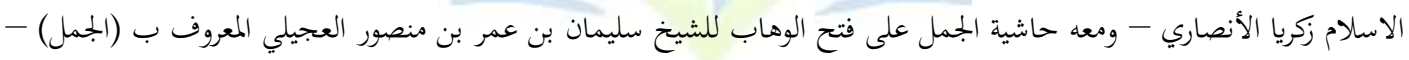

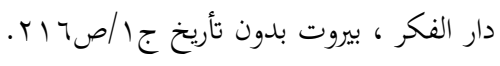

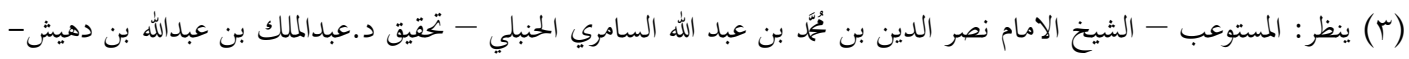

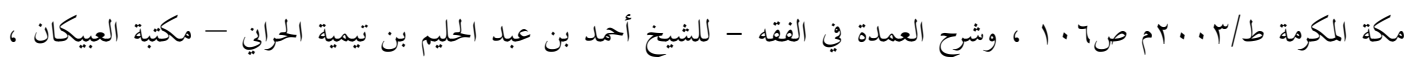

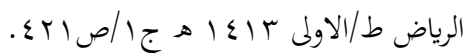

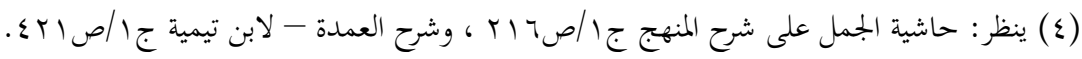

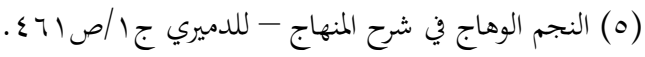

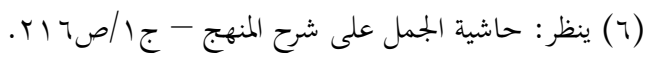

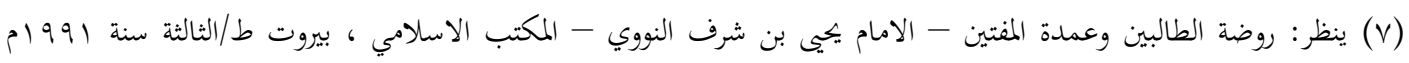

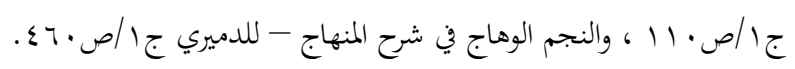

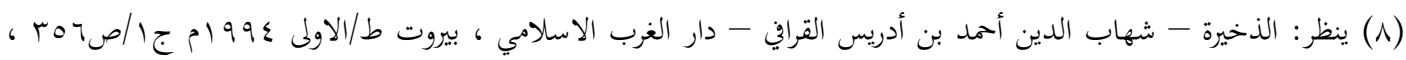

\section{TYS}

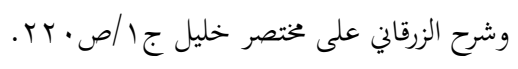


واليه ذهب أكثر الحنابلة وهو الصحيح من مذهبهم.(') واستدلوا:

بقوله سبحانه: فَفَتَيَمَمُوا صَعِيدًا طَِيًَّا

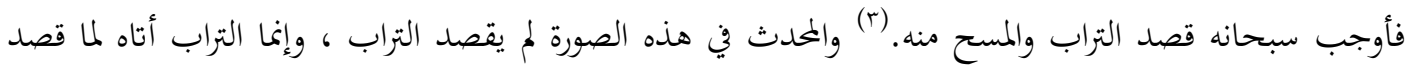

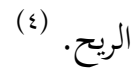
ويرد عليهم: بأنه لم يقصد ذات الرياح ، وانما قصد التراب الذي تحمله ليتيمم به. التزبيح:- ويردئ والذي أميل اليه هو القول الثاني ، الذي ذهب الى أن المحدث إذا قصد تراب الريح حال هبوبها مستحضراً نية

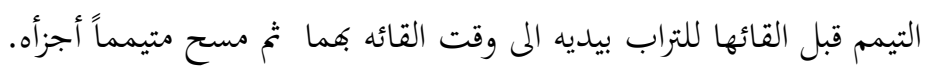

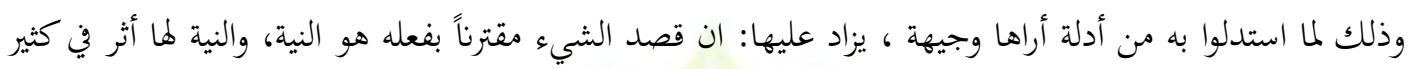

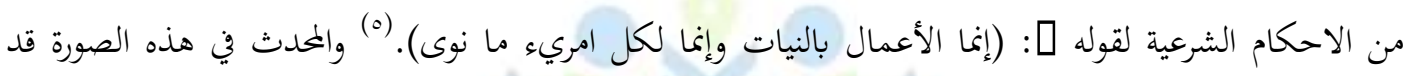

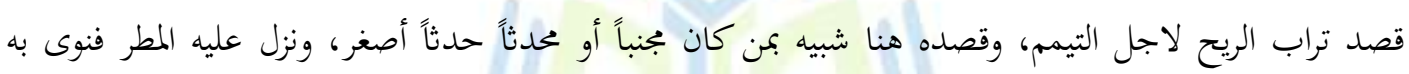

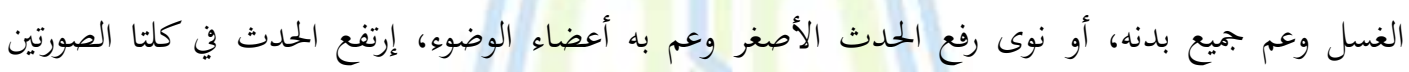

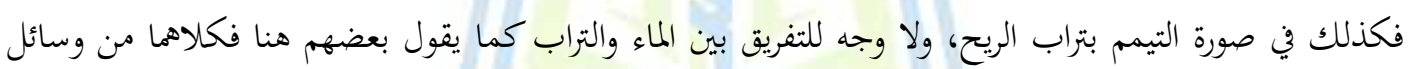
الطهارة ، وإن كان الماء أقوى. يزاد على ذلك: كما أن النقل ليس شرطاً في طهارة الماء وهي أصل كذلك لايكون شرطاً في طهارة البدل، والتفريق بينهما يمتاج الى دليل واضح بحسب دأيي المتواضع ولا دليل هنا...... والله أعلم.

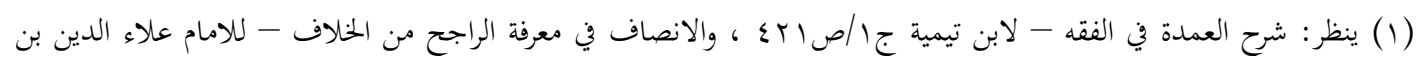

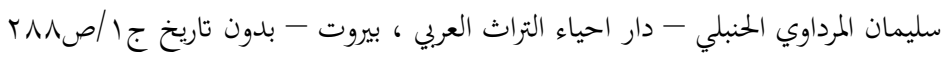

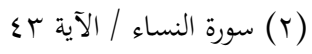

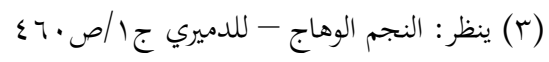

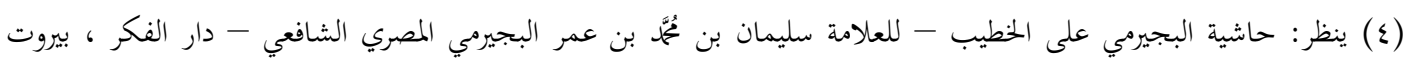

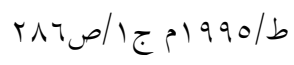

$$
\begin{aligned}
& \text { (0) أخرجه الأمام البخاري في صحيحه برقم (1) ج)/صح }
\end{aligned}
$$

ro 


\section{المسألة: حكم تطهير الرياح للأرض المتنجسة-:}

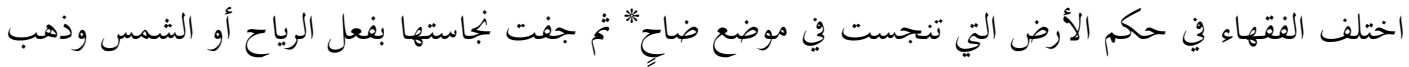

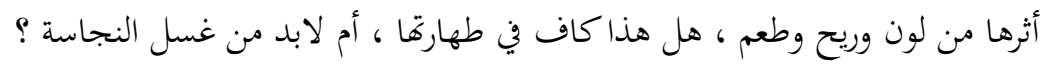
على أربعة أقوال:

القول الأول: تطهر هذه الأرض المتنجسة إذا جفت بفعل الشمس أو الرياح وذهب أثر النجاسة، فتجوز الصلاة

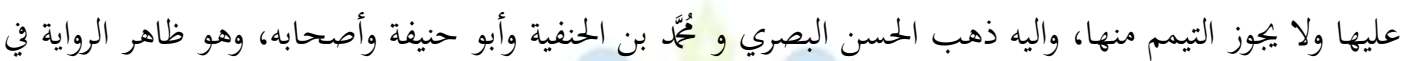

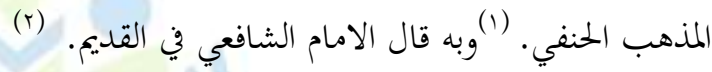
واستدل اصحاب هذا القول بما يأتي:

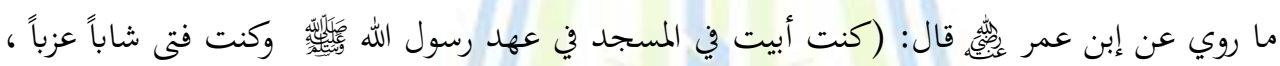

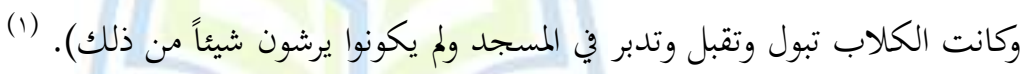

(1)*ضاح: أي بارز ، والضاحي من كل شيء: البارز الظاهر الذي لايستره منك حائط ولا غيره ، وضواحي كل شيء: نواحيه البارزة

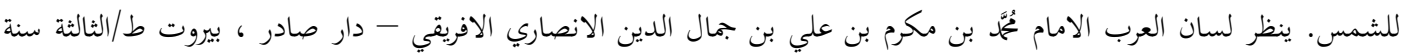

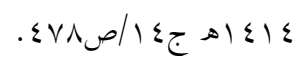
ينظر: النتف في الفتاوى - لأبي الحسن بن علي بن الحسن السغاءي - تحقيق: د.صلاح الدين الناهي - دار الفرقان ، عمان

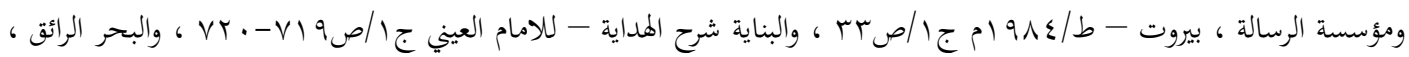

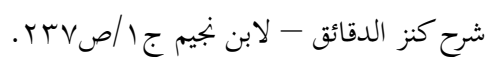

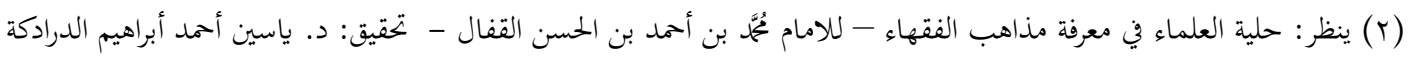

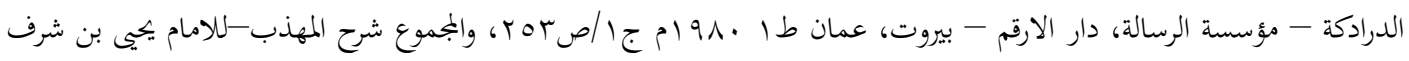
rTt

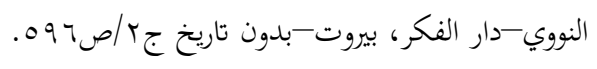


والحديث فيه دليل على أن الأرض إذا أصابتها نجاسة فجفت بالشمس أو الهواء فذهب أثرها تطهر إذ عدم الرش

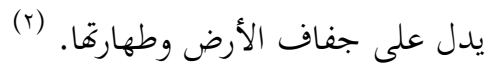
وأجيب: يتأول على أها كانت تبول خار الارض وطهارفا المسجد في مواطنها وتقبل وتدبر في المسجد ، إنما كان أقباها وإدبارها

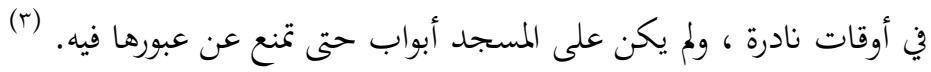

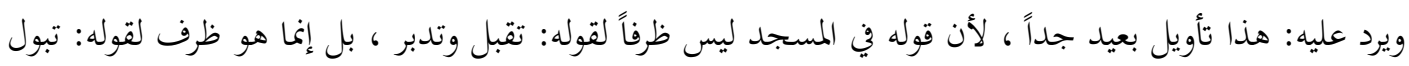

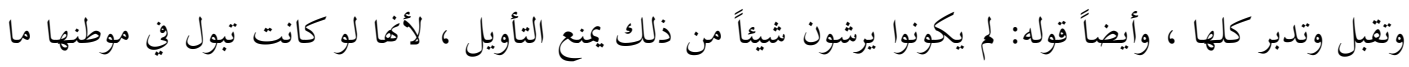

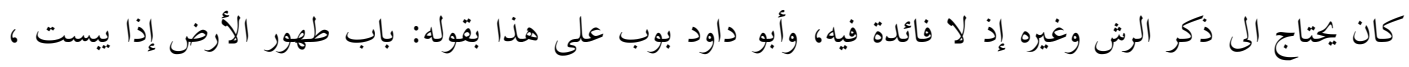

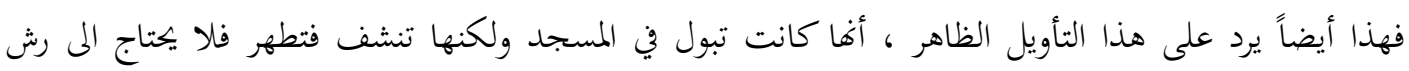
(ई) الماء)

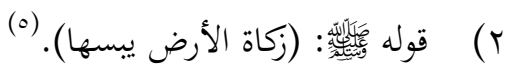

وجه الدلالة: أن طهارة الأرض من النجاسة هو جفافها.

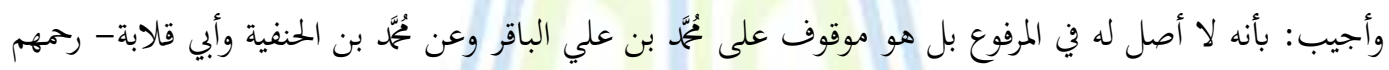

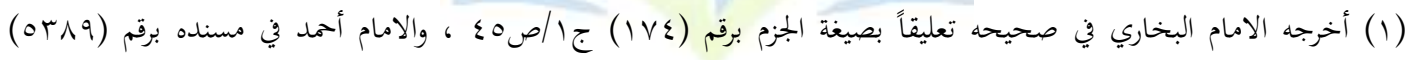

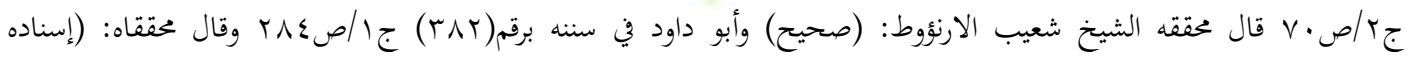
صحيح). (1)

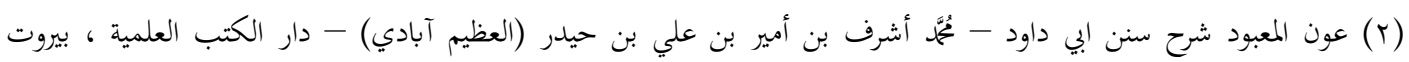

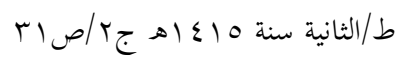

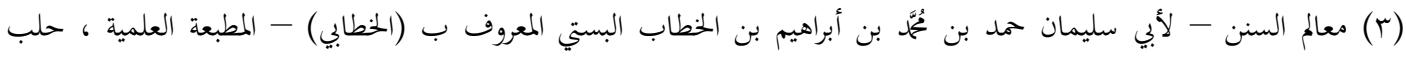

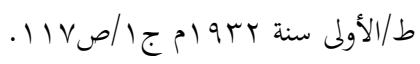

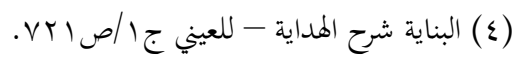

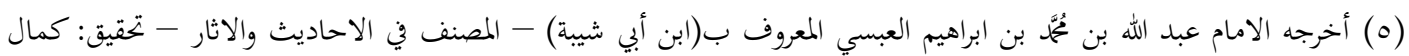

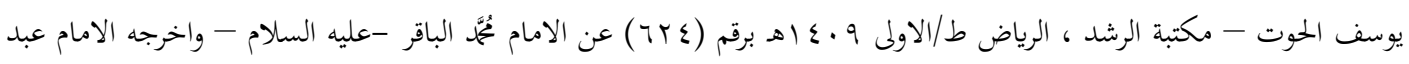

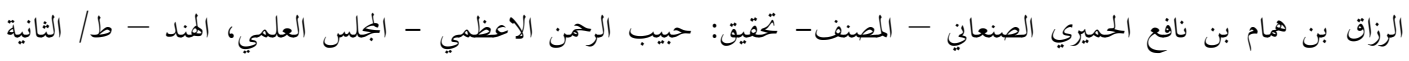

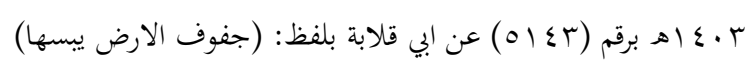
TTV 
r) إن لإحراق الشمس ونسف الرياح أثرها في تقليل النجاسة ، والنجاسة القليلة معفو عنها لا تمنع جواز

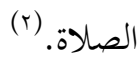

$$
\text { ع) لأنه لم يبق من النجاسة إلا أثرها فهي كما لو غسلت بالماء.(r) }
$$

ه) إن النجاسة تحرقها الشمس وتفرقها الريح وتحول عينها الأرض وينشفها الهواء فلا تبقى عينها بعد تأثير

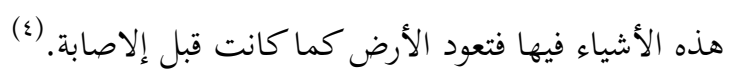

7) أما عدم جواز التيمم ههذا الموضع فلأن الصعيد قبل التنجس كان طاهراً وبالتنجس زال الوصفان

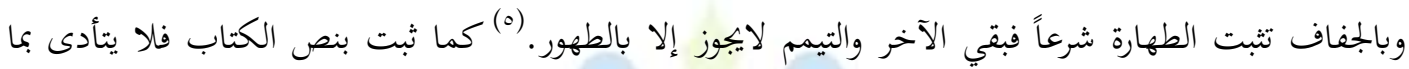

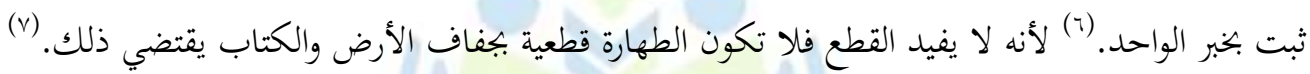

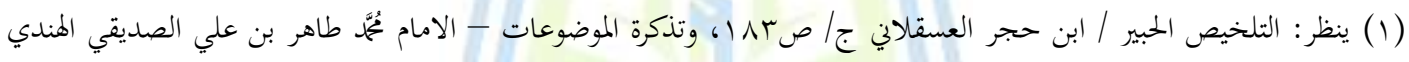

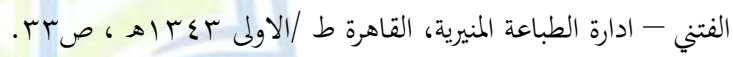

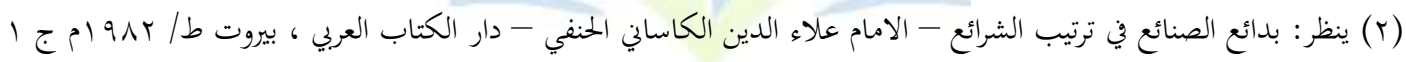

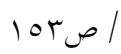

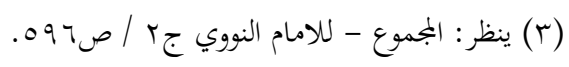

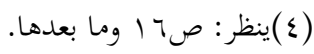

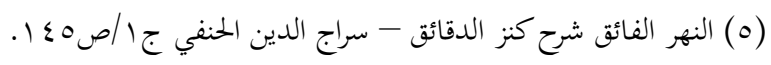

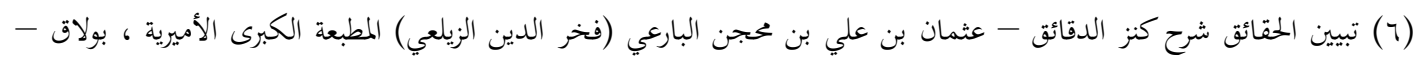

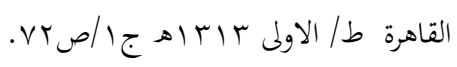

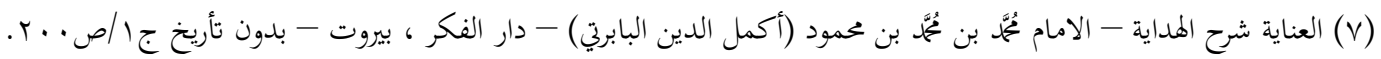

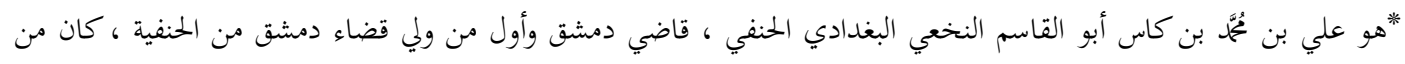

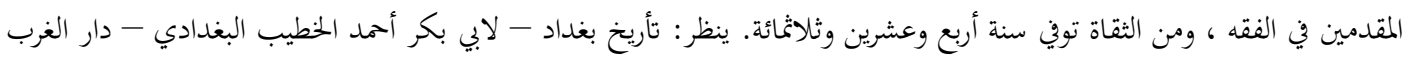

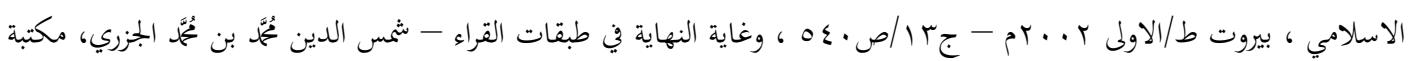
rTA

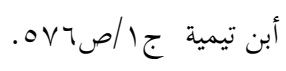


القول الثاني: تطهر هذه الأرض المتنجسة، اذا جفت بغعل الشمس أو الرياح ويبوز الصلاة عليها والتيمم بها، وهو

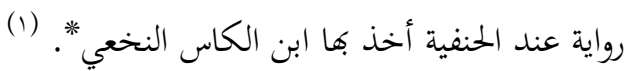

ودليل هذا القول أدلة أصحاب القول الأول: (r)

أما دليله عن جواز الصلاة على هذه الأرض والتيمم بكا فقال: بأن القياس يقتضي أن تجوز الصلاة عليها كما يجوز

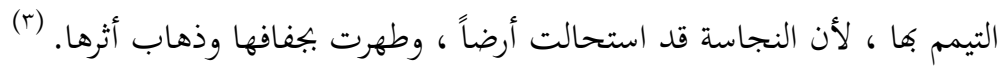

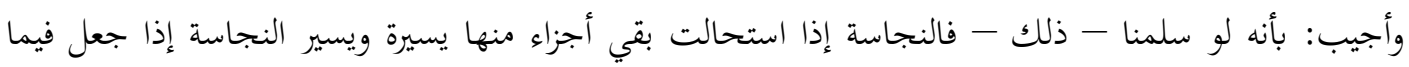

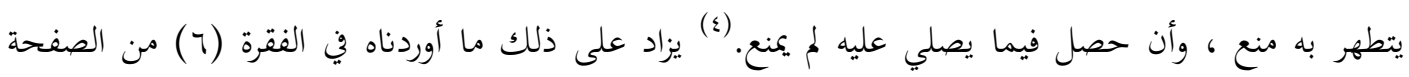
السابقة فلا نكرره هنا.

القول الثالث: لا تطهر هذه الأرض بالرياح ولا بالشمس ولا بلد من غسلها لازالة النجاسة ، وهو مذهب الأئمة

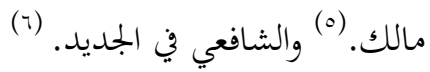
وأحمد. (ل) والإمام زفر من الحنفية. (^) وأبي ثور وأبن المنذر.

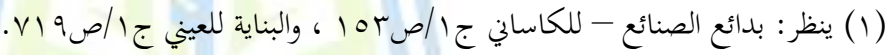

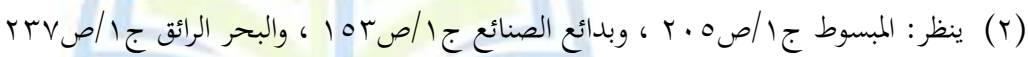

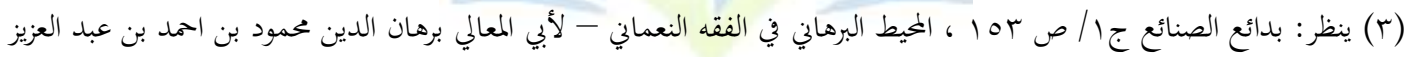

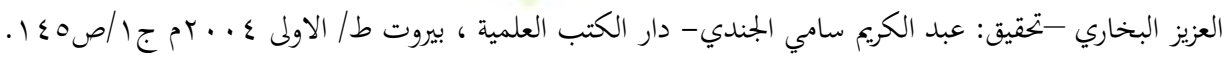

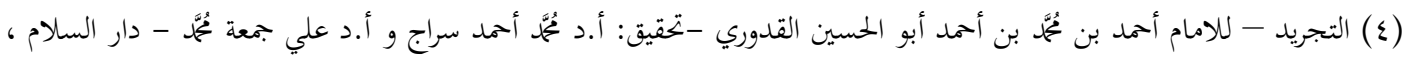

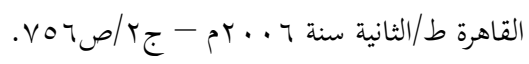

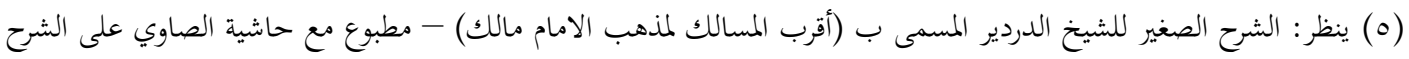

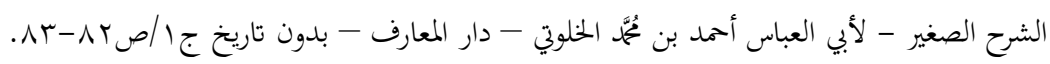

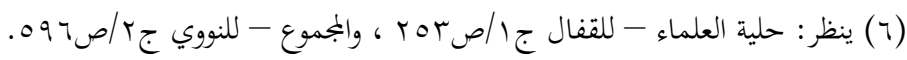

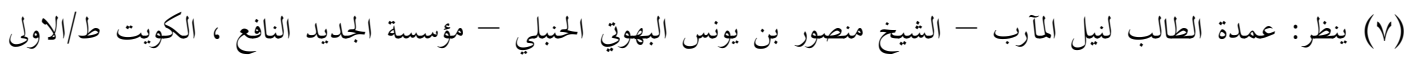

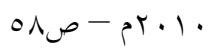

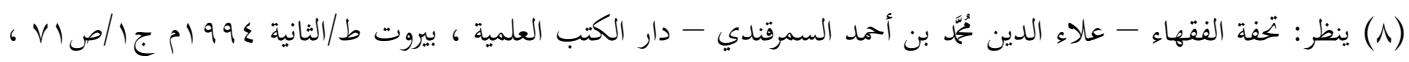

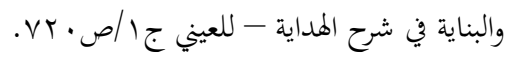

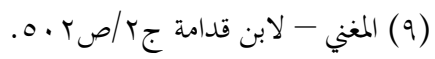

rrq 


\section{واستدلوا بما يأني:}

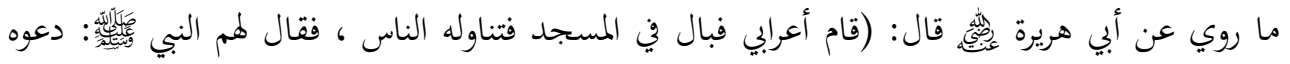

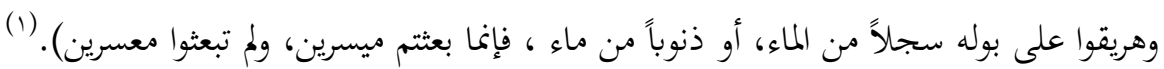

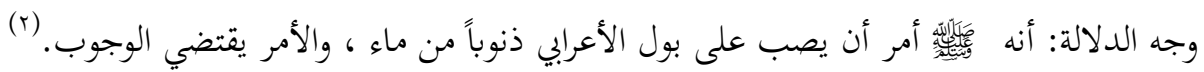

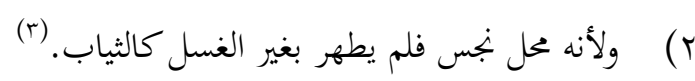

وأجيب: بأن الأرض من طبعها أن تحيل الأشياء وتنقلها الى طبعها فتطهر بالاستحالة كالخمر إذا تخلل بخلاف الثوب. (8)

القول الرابع : لا تطهر الارض المتنجسة كبوب الرياح، وتطهر اذا اشرقت عليها الشمس وأزالت عين النجاسة،

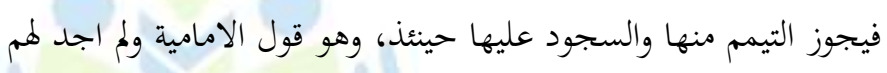

دليلاً فيما ذهبوا اليه بكسما بين يدي من مصادر. (o)

التزجيح:- والذي أميل إليه هو القول الأول، والذي يقضي بطهارة الأرض المتنجسة أذا جفت بنعل الشمس أو أولائ

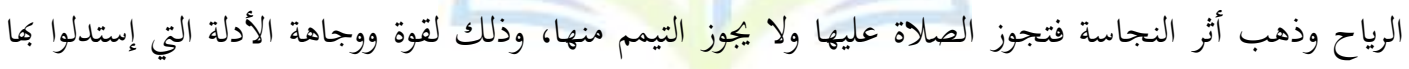

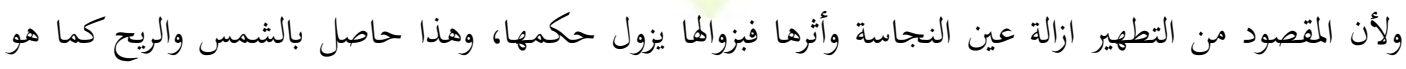

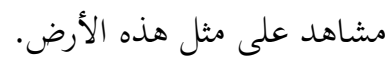

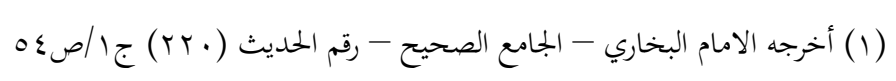

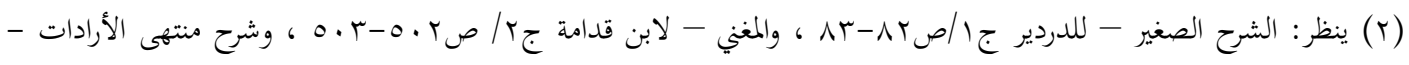

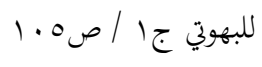

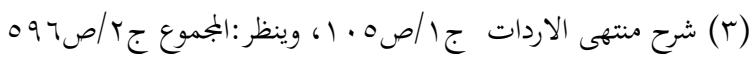

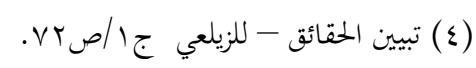

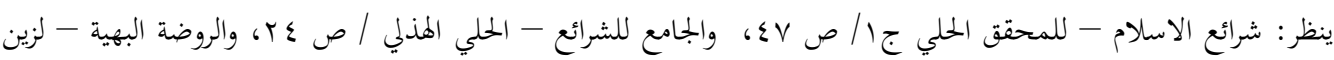

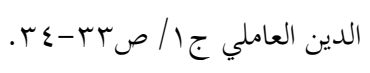

rr. 
ويعضد ذلك ترجيح الامام إبن قيم الجوزية - رمه الله - لهذا الرأي قائلاً:(قال إبو البركات بن تيمية: وهذا كله

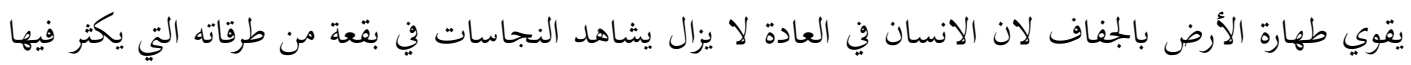

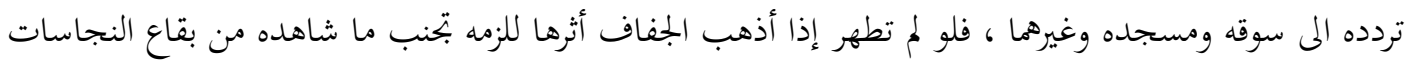

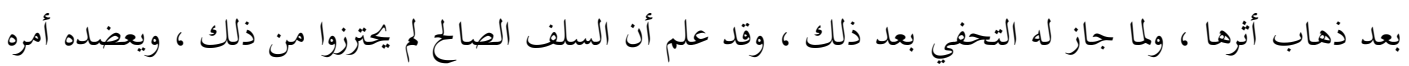

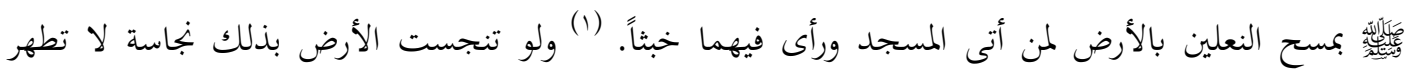
بالجفاف لأمر بصيانة طريق المسجد عن ذلك لأنه يسلكه الحافي وغيره.)(r) والله تعالى فئل أعلم.

المطلب الثاني: احكام الرياح المتعلقة بالدباغ:- وفهة وفيه مسألة واحدة:

\section{المسألة: حكم دباغة الرياح لجلود الحيوانات:-}

اختلف الفقهاء -رحمهم الله - هل تعد الرياح وسيلة لدباغة جلود الحيوانات أم لا؟ على قولين:

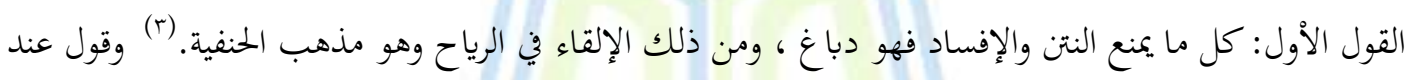
الحنابلة. (๕) الحول:

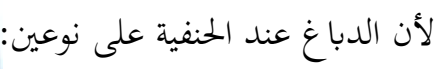

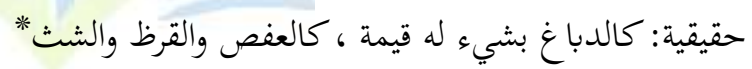

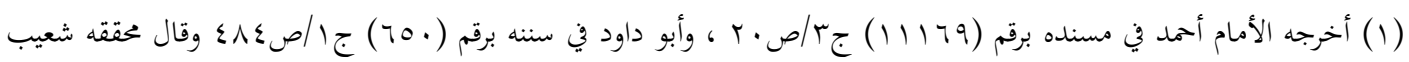

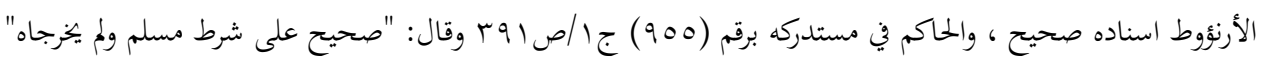

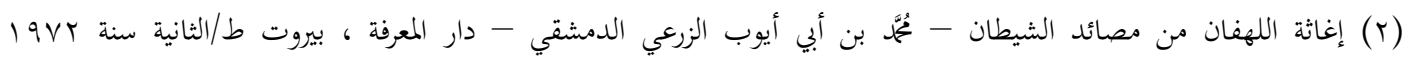

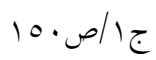

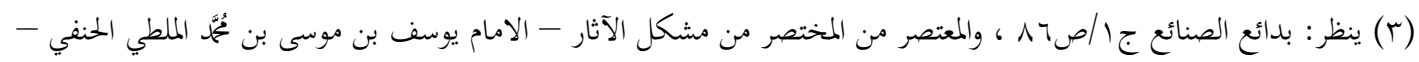

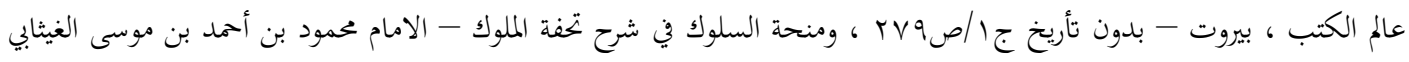

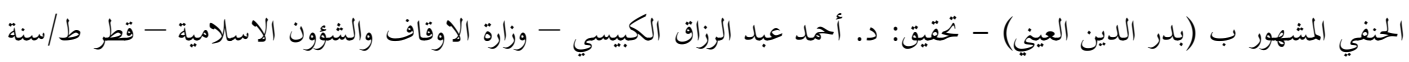
squpr...

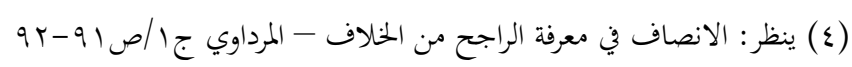

וT 
وحكمية: كالتتريب والتشميس والإلقاء في الرياح. (1) ودليلهم في جواز الدباغة بالإلقاء في الرياح:

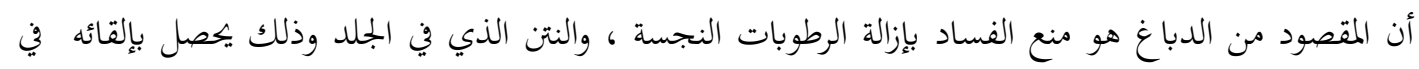

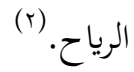
القول الثاني: لاتعد الرياح نوعاً من أنواع الدباغة ، ولا تجزئ فيها ، وهو مذهب المالكية. (r) والشافعية. (ع) والراجح

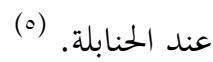

ودليلهم: لأن الفضلات لم تزل من الجلد ، وانما جفت أو جمدت ، بفعل هواء الرياح ، بدليل أنه متى ما نقع في الماءء ، فستعود اليه العفونة(؟).

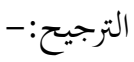

والذي أراه في هذه المسألة هو: أن يرجع فيها الى أهل الخبرة فإن قالوا: إن الرياح تفعل في الجلد فعل المواد التي

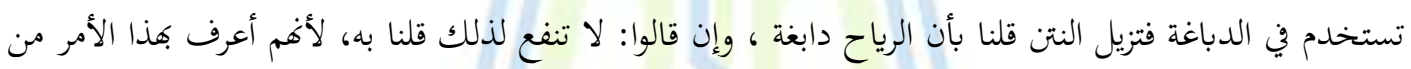
غيرهم فينغي الرجوع اليهم في ذلك.... والله تعالى أعلم.

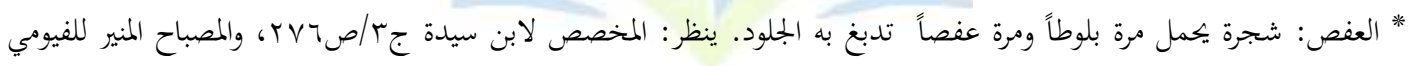

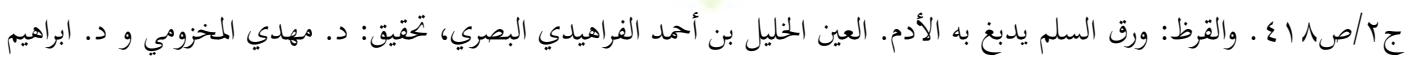

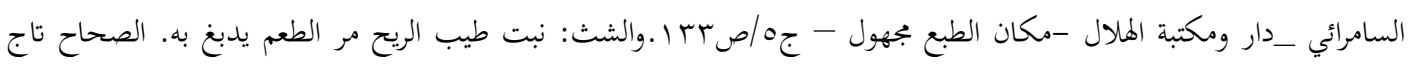

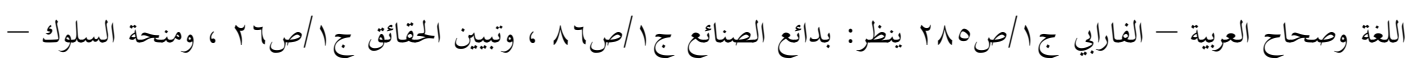

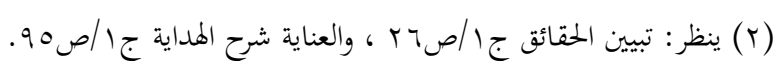

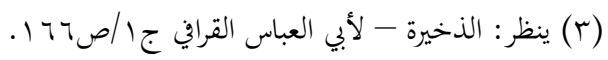

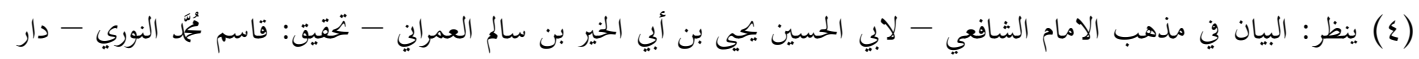

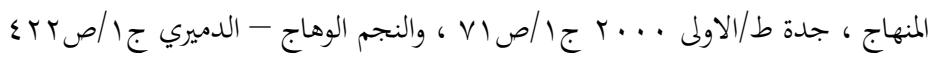

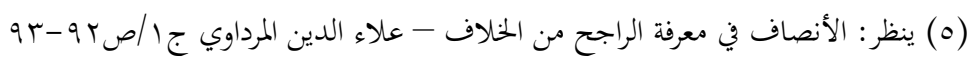

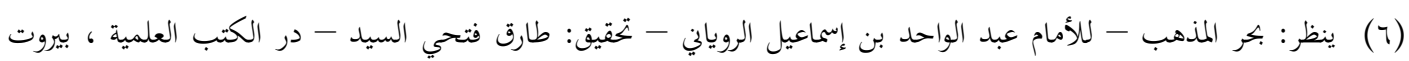

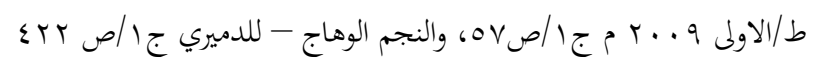

rrT 
الحمد لله في البدء والمتام والصلاة والسلام على سيد الأنام يُمّم وعلى آله وصحبه الكرام.

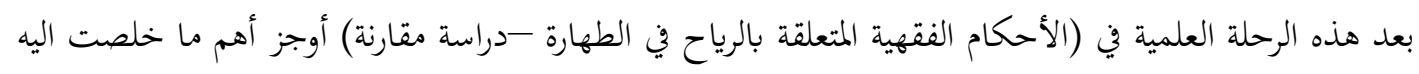

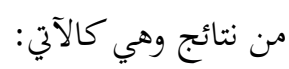
1- الفرق بين الرياح والريح: أن غالب ما في القرآن من لفظ الجمع أي: ((الرياح)) فعبارة عن الرمة ، وغالب ما

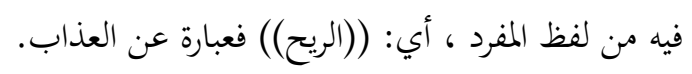

r- اذا سقطت في الماء بعض الاوراق أو التبن أو الحشائش بفعل الرياح فالراجح والله أعلم أنه يبقى طهوراً ما دام

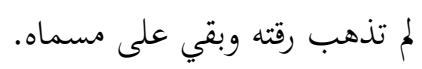

r- أذا بلغ الماء قلتين فينجس إذا تغير بالنجاسة وان كان التغير يسيراً ، ولايعود طاهر اذا زال التغير كبوب الرياح. ع - للرياح أثر في الموالاة في الوضوء ولكن لا تبطله لأن الموالاة سنة في الوضوء.

هـ يكره التبول والتغوط في مهب الريح باتفاق الفقهاء ، لثلا يعود على قاضي الحاجة رشاش بوله أو غائطه ، أو روائح الغائط إن كان صلباً.

ج- إذا قصد الخددث تراب الرياح حال هبوبها مستحضراً نية التيمم قبل القائها التراب بيديه الى وقت القائه بكما ثم مسح متيمماً أجزأه

V- تطهر الأرض الضاحية المتنجسة إذا جفت نجاستها بفعل الشمس أو الرياح وذهب أثر النجاسة وييوز الصلاة عليها دون التيمم. ^- إذا قال أهل الخبرة إن الرياح تفعل في الجلد فعل المواد التي تستخدم في الدباغة أخذ بقولم. واخيراً.... أرجو أن أكون قد أسهمت في بثثي المتواضع بخدمة مكتبة الفقه الإسلامي بما فيه نفع لطلبة العلم والباحثين.. وآخر دعوانا الحمد الله رب العانلمين. ألمهي.

rrr 


\section{المصادر والمراجع بعد القرآن الكريم}

1) إغاثة اللهفان من مصائد الشيطان - مُحَّمَ بن أيوب الزرعي الدمشقي -دار المعرفة، بيروت ط/ الثانية $.019 \vee 0$

r) اقرب المسالك الى مذهب الامام مالك - مطبوع مع حاشية الصاوي على الشرح الصغير - لابي العباس احمد بن مُحمَّم الخلوتي - دار المعارف، بدون تاريخ.

r) الاقناع في فقه الامام أحمد بن حنبل - موسى بن أحمد بن موسى الحجاوي المقدسي - دار المعرفة، بيروت.

ع) الانصاف في معرفة الراجح من الخلاف - الامام علاء الدين علي بن سليمان المرداوي الحنبلي - دار إحياء التراث العربي - بيروت، لبنان - بدون تأريخ.

ه) البحر الرائق شرح كنز الدقائق - زين الدين إبراهيم ابن نجيم الحنفي - دار الكتاب الاسلامي، بيروت بدون تأريخ.

7) بحر العلوم - لأبي الليث نصر بن مُحَّمَ السمرقندي الحنفي - تحقيق: د. محمود مطرجي - دار الفكر ، بيروت - بدون تاريخ.

V ) بحر المذهب - للامام عبدالواحد بن اسماعيل الروياني - تحقيق: طارق فتحي السيد - دار الكتب العلمية،بيروت ط/ الاولى 9 . . ب م.

rT纟 
Published by the College of Islamic Sciences at the University of Fallujah

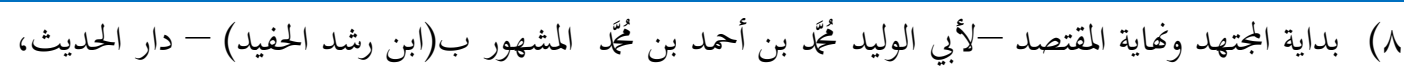
القاهرة ط/ سنة ؟ . - ب بم.

9) بدائع الصنائع في ترتيب الشرائع - علاء الدين أبو بكر بن مسعود الكاساني، دار الكتاب العربي، بيروت سنة 19人 ام.

• (1) البدر المنير في تخريج الاحاديث والاثار الواقعة في الشرح الكبير -سراج الدين عمر بن علي بن أحمد الشافعي الشهير ب(ابن الملقن) - دار الهجرة السعودية ط/ الاولى ع . . بم.

1) بلغة السالك لأقرب المسالك الى مذهب مالك - الشيخ أحمد بن يُمَّمَ الخلوتي الصاوي - دار المعارف، بيروت - بدون تأريخ.

r (1)بلوغ المرام من أدلة الاحكام - لابي الفضل شهاب الدين أحمد بن علي بن حجر العسقلاني - تحقيق: ماهر ياسين فحل - دار القبس ، الرياض ط/الاولى ع ا ب rم.

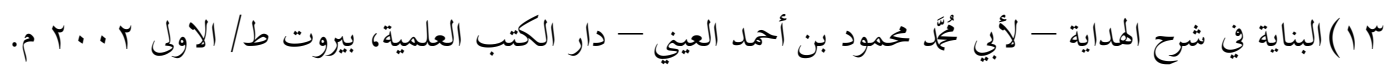
ـ () البيان في مذهب الامام الشافعي - لابي الحسين يهيى بن ابي الخير بن سالم العمراني - تحقيق: قاسم عُمَّم النوري - دار المنهاج، جدة ط/ الاولى . . . بم. 


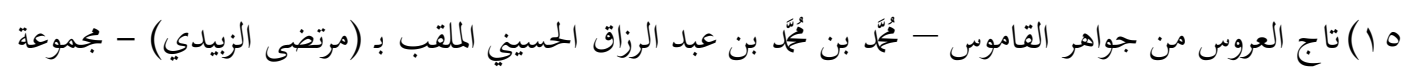
من المققين دار المداية- مكان الطبع مجهول.

7 (1) التاج والاكليل لمختصر خليل - نمُجّم بن يوسف العبدري الغرناطي الشهير ب(المواق) - دار الكتب العلمية، بيروت ط / 199 م م.

$$
\text { IV تأريخ بغداد- لأبي بكر أحمد الخطيب البغدادي دار الغرب الاسلامي، بيروت ط/ الاولى r . F م. }
$$

11) تبيين الحقائق في شرح كنز الدقائق -فخر الدين عثمان بن علي الزيلعي - المطبعة الاميرية الكبرى - بولاق،

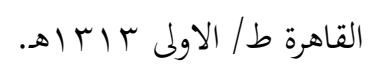

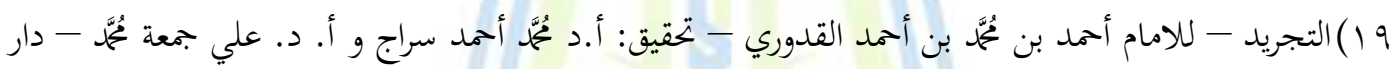
السلام، القاهرة ط/ الثانية V . . rم.

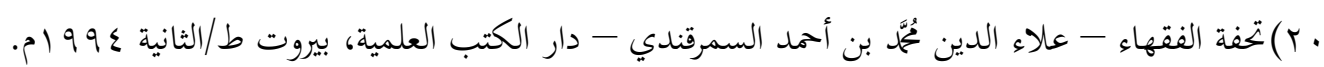

ا (Y) تذكرة الموضوعات - الامام عُمَّم بن طاهر بن علي الصديقي الهندي الفتني - دار الطباعة المنيرية ، القاهرة

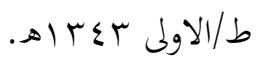

r r التذهيب في أدلة متن الغاية والتقريب - د. مصطفى البغا - دار المصطفى، دمشق ط/ الثانية ـ ـ ب م. 
rr التقريرات السديدة في المسائل المفيدة -الشيخ حسن بن أحمد بن عُمَّم الكاف - دار العلم والدعوة ، اليمن ط/

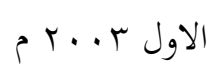

گ أتلخيص في معرفة أسماء الاشياء - لأبي هلال الحسن بن عبدالله بن سهل بن سعيد العسكري - تحقيق: د. عزة حسن -دار طلاس للدراسات والترجمة والنشر، دمشق ط/ الثانية 999 ام.

0) التلخيص الحبير في تخريج أحاديث الرافعي الكبير - لابي الفضل أحمد بن علي بن حجر العسقلاني - دار الكتب العلمية ، بيروت ط/الثالثة ب . ب بم.

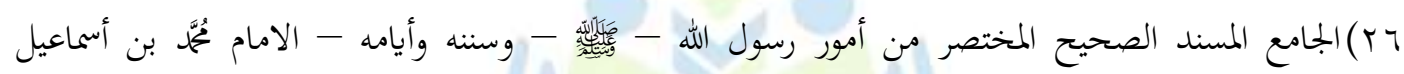

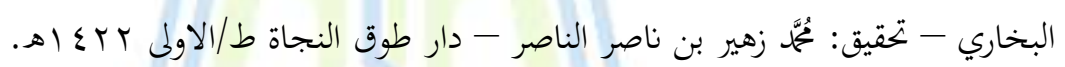

(rV الجامع لاحكام القران - لابي عبد الله ثُحَّهَ بن أحمد القرطبي - تحقيق: هشام سمير بخاري - دار عالم الكتب ،

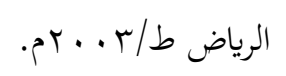

1 الجامع للشرائع - للفقيه يجيى بن سعيد الحلي الهذلي - مؤسسة سيد الشهداء العلمية - قم ، ايران . $ه \leqslant .0 / b$

9 Y) الجغرافية المناخية والنباتية - عبدالعزيز طريح شرف- دار المعرفة الجامعية ، مصر 
• r) حاشية الجمل على فتح الوهاب - الشيخ سليمان بن عمر بن منصور العجيلي الازهري المعروف ب

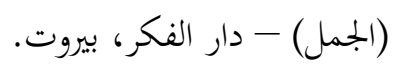

ا (r) حاشية الدسوقي على الشرح الكبير - الامام مُمَّمَ بن عرفة الدسوقي - دار الفكر، بيروت - بدون تأريخ.

كاشية رد المحتار على الدر المختار - مُحمّة أمين الدمشقي (ابن عابدين) - دار الفكر، بيروت ط/ الثانية .1994

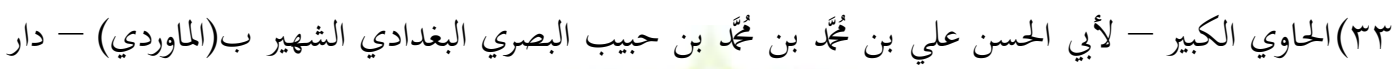
الكتب العلمية، بيروت ط/ الاولى 999 ام.

ع r) حلية العلماء في معرفة مذاهب الفقهاء - الامام مُحّمّ بن أحمد بن الحسين القفال - تحقيق: د. ياسين أحمد ابراهيم الدرادكة - مؤسسة الرسالة، دار الارقم - بيروت، عمان ط/ • 19 ام.

هץ) خلاصة الاحكام في مهمات السنن وقواعد الاسلام - مؤسسة الرسالة ، بيروت ط/الاولى ل99 ام.

דr) درر الحكام شرح غرر الاحكام - مُحَّة بن فراموز بن علي الشهير ب (منلا خسرو) - دار إحياء الكتب العربية - بدون تأريخ.

VrV الذخيرة - شهاب الدين أحمد بن ادريس القرافي - دار الغرب الاسلامي، بيروت ط/الاولى \&99 م.

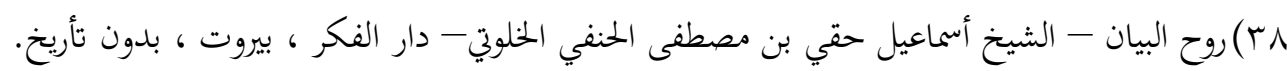
rTh 
9 و) الروضة البهية في شرح اللمعة الدمشقية - الشيخ زين الدين العاملي - دار التفسير ، قم -ايران طا السابعة

• ع) روضة الطالبين وعمدة المفتين -الامام يجيى بن شرف النووي - المكتب الاسلامي، بيروت - ط/ الثالثة

(ع) سنن أبن ماجة - لابي عبد الله مُحَّمَ بن يزيد القزويني - تحقيق: شعيب الارنؤوط وآخرون - دار الرسالة

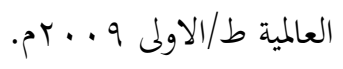

بـ) سنن أبي داود - لابي داود سليمان بن الاشعث الازدي السجستاني - تحقيق: شعيب الارنؤوط ومُحمّ كامل قره بللي - دار الرسالة العالمية ، مكان الطبع مجهول ط/الاولى 9 . ب ؟م.

rأ) سنن الترمذي - لابي عيسى عُمَّمَ بن عيسى الترمذي - تحقيق: بشار عواد معروف - دار الغرب الاسلامي ، بيروت ط/991 ام م.

§ §) سنن الدارقطني - لابي الحسن علي بن عمر الدارقطني - حققه: شعيب الارنؤوط وآخرون - مؤسسة الرسالة

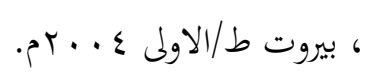

هـ) السنن الكبرى - لابي بكر أحمد بن الحسين بن علي البيهقي - تحقيق: مُحَّمَ عبد القادر عطا - دار الكتب العلمية ، بيروت ط/الثالثة ب. . ب م. 
كـ) سنن النسائي همامش شرح السيوطي وحاشية السندي - مكتبة تحقيق التراث - دار المعرفة ، بيروت

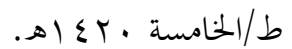

$$
\text { \&V }
$$

1ـ شرائع الاسلام في مسائل الحلال والحرام - للمحقق نجم الدين جعفر بن الحسن الحلي - دار العلوم ، بيروت

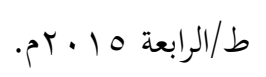

૧ §) شرح الزرقاني على موطأ الامام مالك - الامام مُحمّة بن عبد الباقي بن يوسف المصري الأزهري- تحقيق: طه عبدالرؤوف سعد - مكتبة الثقافة الدينية، القاهرة ط/الاولى r... rم.

• ه) شرح الزركشي على مختصر الخرقي - شثس الدين مُحّمّ بن عبدالله الزركشي الحنبلي - دار العبيكان ط/ الاولى .61994

اه) شرح العمدة في الفقه - للشيخ أحمد بن عبدالحليم بن تيمية الحراني طبعتان طبعة مكتبة العبيكان، الرياض ط/ الاولى با إ (ه)وطبعة: دار الانصاري مكان الطبع جمهور ط/ سنة 997 ام. ro شرح فتح القدير على الهداية - كمال الدين مُحَّمَ بن عبدالواحد السيواسي السكندري - دار الفكر، بيروت - بدون تأريخ.

re. 
rه) شرح مختصر خليل - الامام عبدالباقي بن يوسف بن أحمد الزرقاني - دار الكتب العلمية، بيروت ط/ الاولى

$$
\text { P r. r }
$$

ـ ه)شرح غختصر خليل - الشيخ مُحَّمَ بن عبدالله الخرشي المالكي - دار الفكر، بيروت - بدون تأريخ.

0هـ) شمس العلوم ودواء كلام العرب من الكلوم - نشوان بن سعد الحميري اليمني - دار الفكر المعاصر، بيروت

$$
\text { ودار الفكر، دمشق ط/ الاولى } 999 \text { ام. }
$$

7ه) الصحاح تاج اللغة وصحاح العربية - لأبي نصر اسماعيل بن حماد الجوهري الفارابي - تحقيق: أحمد عبدالغفور

$$
\text { عطار - دار العلم للملايين، بيروت ط/ الرابعة و ا9 ام. }
$$

V) عمدة الطالب لنيل المآرب - الشيخ منصور بن يونس البهوتي الحنبلي - مؤسسة الجديد النافع - الكويت

$$
\text { ط/ الاولى · r. }
$$

1ه) العناية شرح الهداية- الامام مُمَّمَ بن مُحَّمَ بن محمود (اكمل الدين البابرتي) - دار الفكر بيروت - بدون تأريخ.

وه) عون المعبود شرح سنن أبي داود -مُحّمّ أشرف بن أمير بن علي بن حيدر (العظيم آبادي) - دار الكتب العلمية، بيروت ط/ الثنية سنة 1 إ اهـ.

• ج) العين- الخليل بن أحمد الفراهيدي البصري تحقيق: د. مهدي المخزومي و د. ابراهيم السامرائي - دار ومكتبة الهلال - مكان الطبع بجهول. 
Published by the College of Islamic Sciences at the University of Fallujah

ISSN p.p:2708-3993 / ISSN o.l: 2708-4000

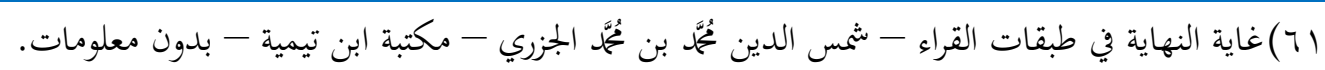

بآTتتح الباري بشرح الصحيح البخاري - لابي الفضل شهاب الدين أحمد بن علي العسقلاين - دار المعرفة ،

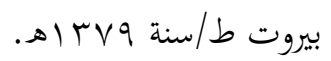

بآ) فتح العزيز بشرح الوجيز -الامام عبدالكريم بن عُمَّمَ القزويني - دار الفكر، بيروت -بدون تأريخ.

ع ب)فتح الوهاب بشرح منهج الطلاب - لشيخ الاسلام زكريا الانصاري - دار الفكر، بيروت - بدون تأريخ.

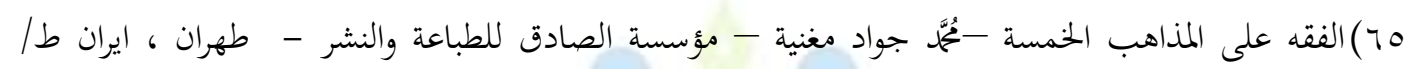
الخامسة - بدون تأريخ.

77) الفواكه الدواني على رسالة أبي زيد القيرواني - الشيخ أحمد بن غانم بن سالم بن مهنا النفراوي - مكتبة الثقافة الدينية، مكان الطبع مجهول.

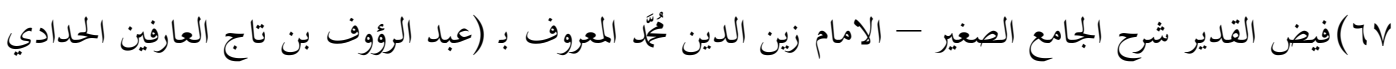
المناوي) - المكتبة التجارية الكبرى ، مصر ط/الاولى بـ أهـ.

14) الكافي في فقه الامام أحمد - موفق الدين عبدالله بن أحمد بن يُحَّم بن قدامة المقدسي - دار الكتب العلمية، بيروت ط/ ع 99 ام. 
97) كشاف القناع عن متن الاقناع - للشيخ منصور بن يونس البهوتي الحنبلي - دار الكتب العلمية، بيروت بدون تأريخ.

كفاية الأخيار في حل غاية الاختصار - لأبي بكر عُمَّمَ بن عبد المؤمن بن حرير الحصني الحسيني - دار الخير،دمشق ط/ الاولى 999 ام.

(V) الكليات - لأبي البقاء أيوب بن موسى الحسيني الكفوي - تحقيق: عدنان درويش وومُحمّ المصري - مؤسسة

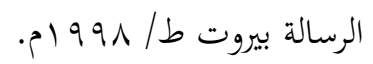

(VT لسان العرب - للأمام يُمَّمَ بن مكرم بن علي بن جمال الدين الانصاري الافريقي - دار صادر ، بيروت ط/الثالثة سنة

(VT المبسوط - شمس الائمة عُمَّمَ بن أحمد السرخسي - دار المعرفة، بيروت ط/ سنة ب99 99 م. ع) Vجمع الزوائد ومنبع الفوائد - نور الدين علي بن أبي بكر الهيثمي - دار الفكر، بيروت ط/ إع اهـ. المجموع شرح المهذب - للامام يحي بن شرف النووي - دار الفكر، بيروت، بدون تأريخ. الميط البرهاني في الفقه النعماني - لابي المعالي برهان الدين محمود بن أحمد بن عبدالعزيز البخاري- تحقيق: عبدالكريم سامي الجندي - دار الكتب العلمية، بيروت ط/ الاولى ع . . بم. 
المخصص - لابي الحسن علي بن اسماعيل بن سيده المرسي - تحقيق: خليل ابراهيم جفال - دار احياء

$$
\text { التراث العربي، بيروت ط/ الاولى } 997 \text { ام. }
$$

VN) المداوي لعلل الجامع الصغير وشرح المناوي - الحافظ أحمد بن ثُحَّمَ بن الصديق الغماري - دار الكتبي، القاهرة

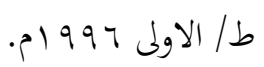

(V9) المستدرك على الصحيحين - لابي عبدالله مُجمّمَ بن عبدالله الحاكم النيسابوري - دار الكتب العالمية، بيروت $. p 199 \leq / b$

• م) المستوعب - الامام نصر الدين عُمَّم بن عبدالله السامري الحنبلي - تحقيق: عبدالملك بن عبدالله بن دهيش مكة المكرمة ط/ +. Tr/م.

1(م)مسند أبي يعلى - الامام أحمد بن علي بن المثنى الموصلي - تحقيق: حسن سليم أسد - دار المأمون للتراث - دمشق ط/ الاولى ع 919 ام.

r)مسند الامام أحمد - الامام احمد بن حنبل الشيباني - تحقيق:شعيب الأرئوط - مؤسسة قرطبة، القاهرة بدون تأريخ.

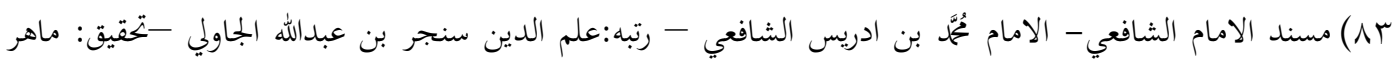
ياسين فحل - غراس للنشر والتوزيع، الكويت ط/ الاولى ؟ . ب ام. 
ع)مسند الحميدي - الامام عبدالله بن الزبير بن عيسى الحميدي - دار السقا، دمشق طا الاولى سنة

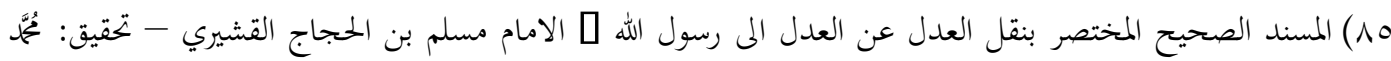
فؤاد عبدالباقي - دار أحياء التراث العربي ، بيروت - بدون تأريخ.

1^) المصباح المنير في غريب الشرح الكبير- أحمد بن ثُمَّمَ بن علي الفيومي - المكتبة العلمية، بيروت- بدون تأريخ.

(AV الاعظمي - المجلس العلمي الهند - ط/الثانية r. أهـ.

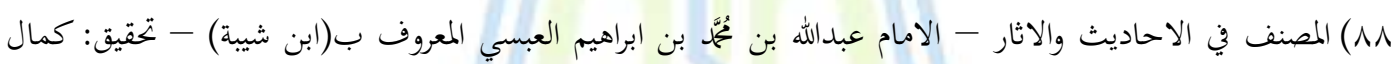
يوسف الحوت - مكتبة الرشد الرياض ط/الاولى 9 .ـ اهـ.

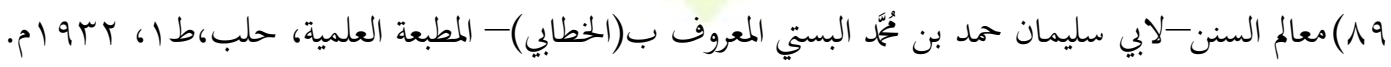
• 9) المعجم الكبير- الامام سليمان بن أحمد بن أيوب الطبراني- مكتبة العلوم والحكم، الموصل طب، بمه ام. (9)معجم المصطلحات والالفاظ الفقهية، محمود عبدالرمن عبدالمنعم، جامعة الازهر - دار الفضيلة-بدون تأريخ. بو) المعجم الوسيط - ابراهيم مصطفى وآخرون - مجمع اللغة العربية، دار الدعوة - القاهرة، بدون تأريخ. 
بو)معرفة السنن والاثار- لأمد بن الحسين البيهقي - تحقيق: سيد كسروي حسن - دار الكتب العلمية،

$$
\text { بيروت - بدون تأريخ. }
$$

§ 9)المغرب في ترتيب المعرب - لأبي الفتح ناصر الدين بن السيد بن علي المطرز - مكتبة أسامة بن زيد، حلب

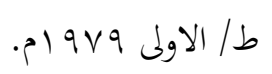

90) المغني - موفق الدين عبدالله بن أحمد بن مُحمَّمَ المقدسي - تحقيق: د. عبدالله بن المحسن التركي ود. عبدالفتاح

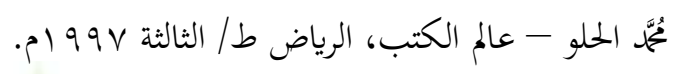

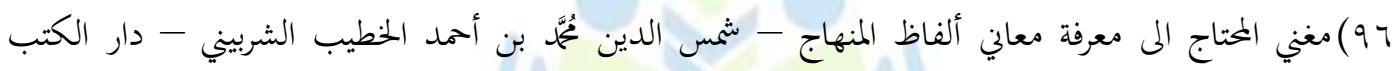
العلمية، بيروت ط/ الاولى \99 1م.

V9) منحة السلوك في شرح تحفة الملوك - الامام محمود بن أحمد بن موسى العيني- تحقيق: د. أحمد عبدالززاق الكبيسي-وزارة الاوقاف والشؤون الاسلامية - قطر ط/V . . بم.

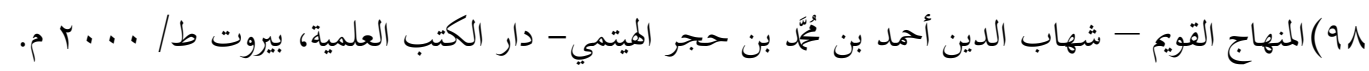
9) الموطأ - الامام مالك بن أنس الاصبحي - مؤسسة الرسالة، بيروت ط/ ا إ اهـ. . . . 1 النتف في الفتاوى - لابي الحسين علي بن الحسين السغدي - تحقيق: د. صلاح الدين الناهي - دار الفرقان، عمان ومؤسسة الرسالة، بيروت ط/ ع 9 ام. 


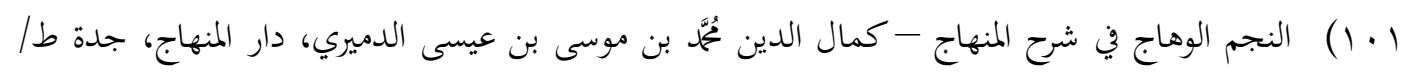

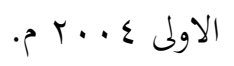

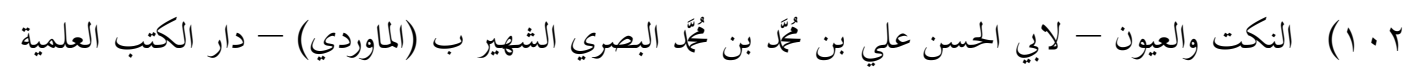
، بيروت - بدون تأريخ.

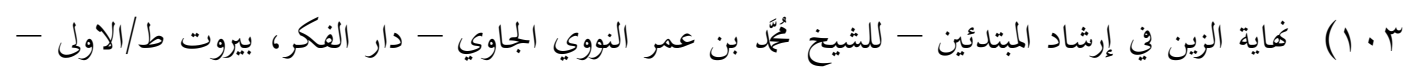
بدون تأريخ.

ع ـ ا ) هاية المطلب في دراية المذهب - لامام الحرمين عبدالملك بن عبدالله بن يوسف الجويني - حققه: أ.

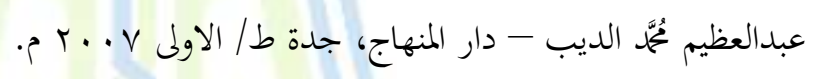

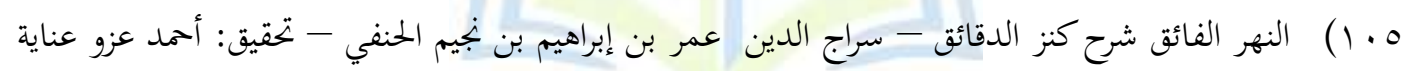
- مار الكتب العلمية، بيروت طا/ الاولى +. Y م.

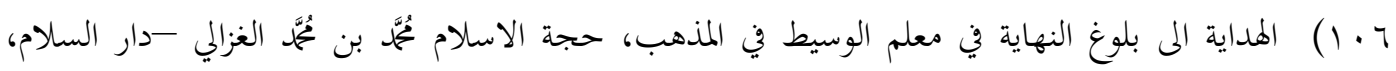

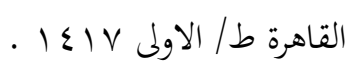

